US Army Corps

of Engineers ${ }_{\circledast}$

Engineer Research and

Development Center

\title{
Little Rock Air Force Base Aggregate and Concrete Testing
}

Jameson D. Shannon

November 2018

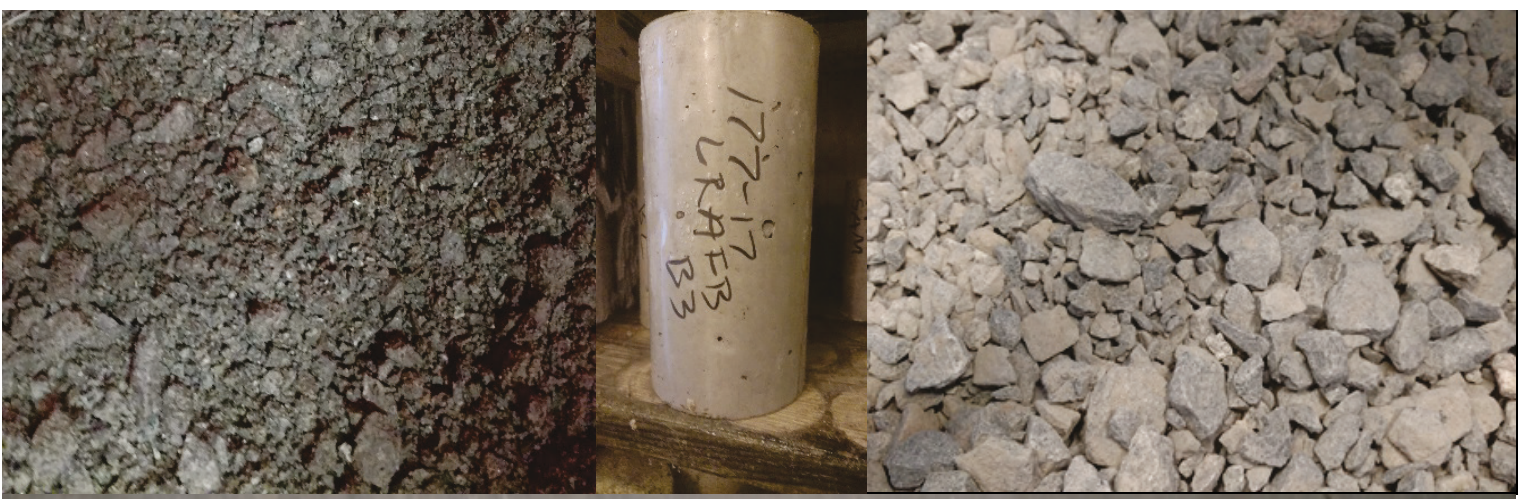


The U.S. Army Engineer Research and Development Center (ERDC) solves the nation's toughest engineering and environmental challenges. ERDC develops innovative solutions in civil and military engineering, geospatial sciences, water resources, and environmental sciences for the Army, the Department of Defense, civilian agencies, and our nation's public good. Find out more at www.erdc.usace.army.mil.

To search for other technical reports published by ERDC, visit the ERDC online library at http://acwc.sdp.sirsi.net/client/default. 
ERDC/GSL TR-18-32

November 2018

\title{
Little Rock Air Force Base Aggregate and Concrete Testing
}

\author{
Jameson D. Shannon \\ Geotechnical and Structures Laboratory \\ U.S. Army Engineer Research and Development Center \\ 3909 Halls Ferry Road \\ Vicksburg, MS 39180-6199
}

Final report

Approved for public release; distribution is unlimited.

\footnotetext{
Prepared for USACE Little Rock District

700 W. Capitol Avenue, Federal Building 7th Floor, Little Rock, AR 72203

Under LCC 2EF9E5
} 


\section{Abstract}

The Little Rock Air Force Base (LRAFB) tasked the ERDC to test and evaluate a concrete mixture design and the aggregates used therein. Experimentation consisted of basic aggregate test methods such as gradation, specific gravity, absorption, and organic materials. Concrete testing consisted of manufacturing a laboratory concrete mixture design provided by LRAFB and conducting compressive and flexural strength testing of cast specimens.

In most cases the selected aggregate and concrete mixture design testing met specifications. However, there were some areas, such as aggregate gradations, in which the materials did not align with specified values or standards. Final hardened concrete properties of compressive and flexural strength met the mixture design requirements.

DISCLAIMER: The contents of this report are not to be used for advertising, publication, or promotional purposes. Citation of trade names does not constitute an official endorsement or approval of the use of such commercial products. All product names and trademarks cited are the property of their respective owners. The findings of this report are not to be construed as an official Department of the Army position unless so designated by other authorized documents. 


\section{Contents}

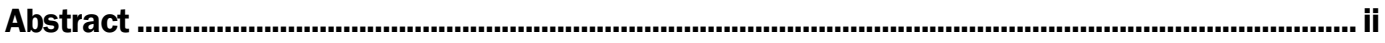

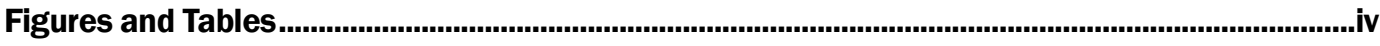

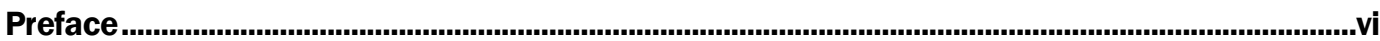

1 Introduction and Background ............................................................................................... 1

2 Experimental Program ................................................................................................................. 2

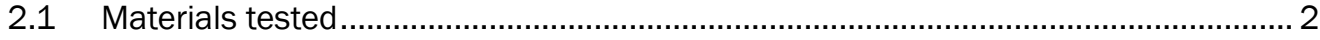

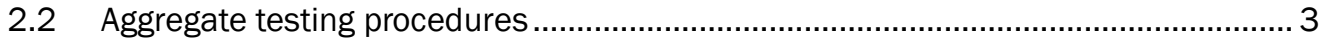

2.3 Concrete mixture design testing procedures .................................................. 4

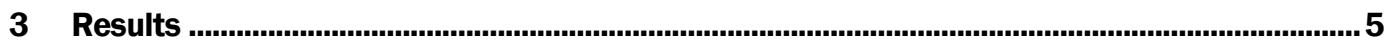

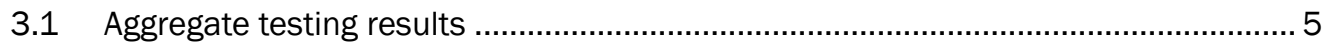

3.2 Combined aggregate testing results.............................................................. 8

3.3 Concrete mixture design results ................................................................ 11

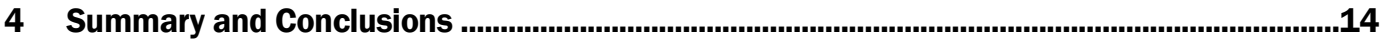

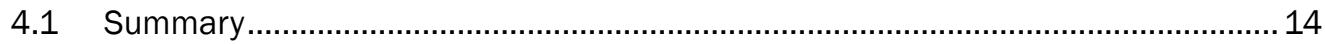

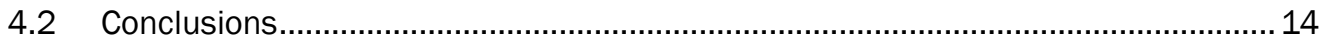

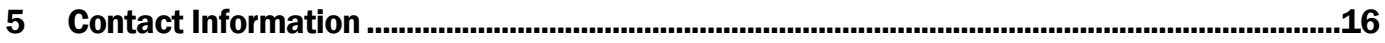

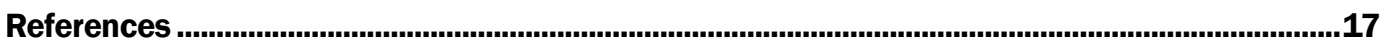

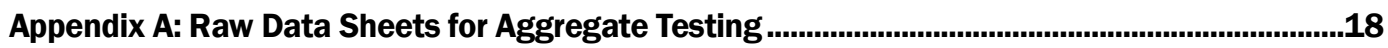

Appendix B: Raw Data Sheets for Concrete Testing ...................................................................31

\section{Report Documentation Page}




\section{Figures and Tables}

\section{Figures}

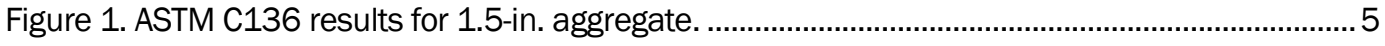

Figure 2. ASTM C136 results for \#57 aggregate. …………............................................................. 6

Figure 3. ASTM C136 results for Product 1 aggregate. ………………………………………......

Figure 4. ASTM C136 results for sand aggregate.................................................................................

Figure 5. Combined percent retained by sieve size...........................................................................

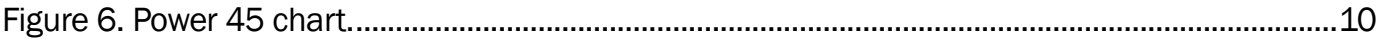

Figure 7. Calculated CF versus WF with limits shown. ……….......................................................11

Figure 8. Specimen photos illustrating unclosed holes..................................................................12

Figure B1. Three-day compressive strength $6 x 12$ cylinder. .............................................................32

Figure B2. Seven-day compressive strength $6 x 12$ cylinder.............................................................33

Figure B3. Fourteen-day compressive strength $6 x 12$ cylinder. ........................................................34

Figure B4. Twenty-eight-day compressive strength $6 \times 12$ cylinder....................................................35

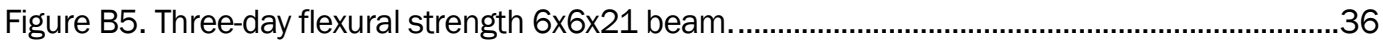

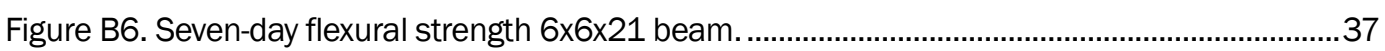

Figure B7. Fourteen-day flexural strength 6x6x21 beam. .............................................................38

Figure B8. Twenty-eight-day flexural strength $6 \times 6 \times 21$ beam......................................................39

\section{Tables}

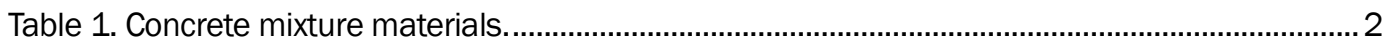

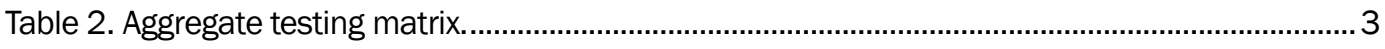

Table 3. ASTM C117 results........................................................................................................ 8

Table 4. ASTM C127 and ASTM C128 test results. …….................................................................

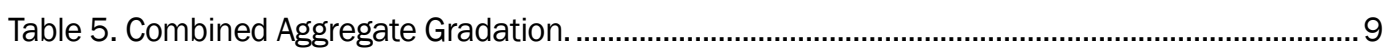

Table 6. Fresh mixed concrete properties..................................................................................

Table 7. Flexural strength results. ..............................................................................................13

Table 8. Compressive strength results (psi). ............................................................................13

Table A1. ASTM C127 for 1.5-in. aggregate..................................................................................18

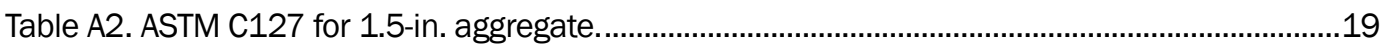

Table A3. ASTM C136 and ASTM C117 precision for 1.5-in. aggregate. ..........................................20

Table A4. ASTM C136 and ASTM C117 for \#57 aggregate. .............................................................21

Table A5. ASTM C127 for \#57 aggregate.....................................................................................22

Table A6. ASTM C136 and C137 precision for \#57 aggregate.........................................................23

Table A7. ASTM C137 and C137 for Product 1 aggregate.................................................................2

Table A8. ASTM C127 and ASTM C128 for Product 1 aggregate. ...................................................2

Table A9. ASTM C128 for Product 1 aggregate.................................................................................26

Table A10. ASTM C136 and C117 precision. ...............................................................................2 


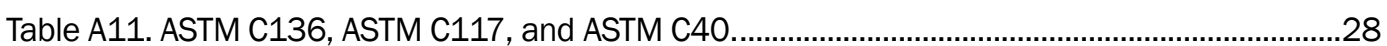

Table A12. ASTM C128

Table A13. ASTM C136 and C117 precision. .................................................................................30 


\section{Preface}

This study was conducted for the U.S. Army Corps of Engineers Little Rock District. The technical monitor was Dr. Jameson D. Shannon.

The work was performed by the Concrete and Materials Branch (GMC) of the Engineering Systems and Materials Division (GM), U.S. Army Engineer Research and Development Center, Geotechnical and Structures Laboratory (ERDC-GSL). At the time of publication, Mr. Christopher M. Moore was Chief, CEERD-GMC; Dr. G. William McMahon was Chief, CEERD-GM; and Ms. Pamela Kinnebrew, CEERD-GTZ, was the Technical Director for Military Engineering. The Deputy Director of ERDC-GSL was Dr. William P. Grogan, and the Director was Mr. Bartley P. Durst.

COL Ivan P. Beckman was the Commander of ERDC, and Dr. David W. Pitman was the Director. 


\section{Unit Conversion Factors}

\begin{tabular}{|l|c|l|}
\hline \multicolumn{1}{|c|}{ Multiply } & By & \multicolumn{1}{c|}{ To Obtain } \\
\hline cubic feet & 0.02831685 & cubic meters \\
\hline degrees Fahrenheit & $(\mathrm{F}-32) / 1.8$ & degrees Celsius \\
\hline feet & 0.3048 & meters \\
\hline gallons (US liquid) & $3.785412 \mathrm{E}-03$ & cubic meters \\
\hline inches & 0.0254 & meters \\
\hline square feet & 0.09290304 & square meters \\
\hline square inches & $6.4516 \mathrm{E}-04$ & square meters \\
\hline yards & 0.9144 & meters \\
\hline
\end{tabular}




\section{Introduction and Background}

The construction and repair of concrete runways is an integral part of the operations of the U.S. Army Corps of Engineers for both military and civilian installations. Recently, issues involving the deterioration of runways by spalling, sometimes referred to as sliver spalling, have been designated as potentially problematic on a large scale. A possible cause of this issue was thought to be aggregate gradations used in the concrete mixture and, accordingly, studies to evaluate mixture gradation's relationship to concrete performance were desired.

This research effort seeks to investigate a concrete runway mixture design, focusing on aggregate gradations, in an attempt to determine the suitability of the mixture design for use. Aggregate gradations restrictions were based on the power 45 curve and workability versus coarseness factor. The mixture was evaluated by compressive and flexural strength, as well as fresh-mixed concrete properties and visual observations. 


\section{Experimental Program}

\subsection{Materials tested}

Testing was conducted on a concrete mixture design with a focus on aggregate materials. The mixture design was originally developed for Little Rock Air Force Base (LRAFB) to be used in concrete paving operations. In total six material samples were obtained, one each of cement, fly ash, 1.5-in. crushed limestone aggregate, \#57 aggregate, intermediate aggregate, and sand. The intermediate aggregate was identified only as "Product 1." Materials and proportions for the concrete mixture are listed in Table 1.

Table 1. Concrete mixture materials.

\begin{tabular}{|l|l|c|c|}
\hline \multicolumn{1}{|c|}{ Material } & \multicolumn{1}{|c|}{ Supplier } & $\begin{array}{c}\text { Weight }(\mathrm{lb}) \text { per } \mathbf{y d}^{3} \text { of } \\
\text { Concrete }\end{array}$ & $\begin{array}{c}\text { Volume }\left(\mathrm{ft}^{3}\right) \text { per } \mathbf{~ y d}^{3} \text { of } \\
\text { Concrete }\end{array}$ \\
\hline Cement & Ash Grove & 428 & 2.18 \\
\hline Fly Ash & Martin Lake & 183 & 1.17 \\
\hline 1.5-in. Agg. & Granite Mtn. & 740 & 4.53 \\
\hline \#57 Agg. & Granite Mtn. & 1040 & 6.34 \\
\hline Product 1 & Granite Mtn. & 396 & 2.42 \\
\hline Sand & Jeffrey & 870 & 5.28 \\
\hline Water & -- & 208 & 3.33 \\
\hline Air & --- & --- & 1.76 \\
\hline
\end{tabular}

Water used in concrete mixing was onsite potable water from Vicksburg, MS. Euclid Admixtures AEA 92 (air entrainment) and Eucon NW (superplasticizer - water reducer) were used at dosage rates of 0.5$2.0 \mathrm{oz} / \mathrm{cwt}$ and $4-6 \mathrm{oz} / \mathrm{cwt}$, respectively.

Sampling was conducted by ERDC personnel at the temporary stockpile locations at Little Rock AFB on 4 April 2017. Stockpiles were first "rolled" to remove the top layer of materials and to facilitate more accurate sampling. Samples of materials were then hand shoveled into 5-gal buckets and transferred to a larger container for transport. Cement, fly ash, and Product 1 were transported in 55-gal drums while 1.5-in., \#57, and sand materials were transported in supersacks. Due to concerns about the age of admixtures at the Little Rock location, fresh admixtures were also collected by the ERDC to be used in the mixture designs. 


\subsection{Aggregate testing procedures}

All aggregate testing was conducted by technicians with appropriate certifications and with equipment that is regularly calibrated and certified by an external laboratory. Aggregates were stored in their transportation containers, either supersacks or 55-gal drums, until tested. Aggregates were placed into a $3-\mathrm{ft}^{3}$ concrete mixing drum and rotated before testing to alleviate any segregation that may have occurred during transportation. Gradations for all four aggregates were determined using ASTM C136 standards. Sieve sizes used for the 1.5 -in. and \#57 materials were 4 in. (100 mm), 3.5 in. (90 mm), 3 in. (75 mm), 2.5 in. (63 mm), 2 in. (50 mm), 1.5 in. $(37.5 \mathrm{~mm}), 1$ in. $(25 \mathrm{~mm}), 0.75$ in. $(19 \mathrm{~mm}), 0.5$ in. (12.5 mm), 0.375 in. (9.5 mm), No. 4 (4.75 mm), and No. 8 (2.36 mm).

For the "Product 1" aggregate, all larger sieve sizes were used, and No. 16 $(1.18 \mathrm{~mm})$ and No. $30(600 \mu \mathrm{m})$ were added. For the sand aggregate all larger sizes were used; and No. $40(425 \mu \mathrm{m})$, No. $50(300 \mu \mathrm{m})$, No. 100 $(150 \mu \mathrm{m})$, and No. $200(75 \mu \mathrm{m})$ were added. ASTM C117 standards were also conducted on all aggregates to determine materials finer than $75 \mu \mathrm{m}$. All ASTM C136 and C117 testing was conducted with two different material samples, and results were based on the average.

Relative densities and absorptions of the 1.5-in., \#57, and Product 1 materials were determined by ASTM C127 standards. Relative densities and absorption of sand were conducted according to ASTM C128 standards. All ASTM C127 and ASTM C128 testing was conducted on two different material samples, and results were based on the average. Organic impurity testing on the sand was conducted according to ASTM C4O standards. A test matrix for aggregate testing with the number of samples shown is in Table 2.

Table 2. Aggregate testing matrix.

\begin{tabular}{|l|c|c|c|c|c|}
\hline \multirow{2}{*}{} & \multicolumn{5}{|c|}{ ASTM Test Method and Number of Samples } \\
\cline { 2 - 6 } & C136 & C117 & C127 & C128 & C40 \\
\hline 1.5 in. & 2 & 2 & 2 & -- & -- \\
\hline \#57 & 2 & 2 & 2 & -- & -- \\
\hline Product 1 & 2 & 2 & 2 & -- & -- \\
\hline Sand & 2 & 2 & -- & 2 & 1 \\
\hline
\end{tabular}




\subsection{Concrete mixture design testing procedures}

All concrete mixing and testing were conducted by technicians with appropriate certifications and with equipment that is regularly calibrated and certified by an external laboratory. Concrete mixtures were batched according to ASTM C192 standards. A single mixture design was batched in triplicate, and each batch had a volume of $3 \mathrm{ft} 3$. The three batches were each mixed, tested for fresh properties, and placed into molds on the same day during a 6-hr period. Immediately after mixing, the batches were tested for fresh mixed properties of slump, air content, and unit weight according to ASTM C143, ASTM C231, and ATM C138 standards, respectively.

After fresh property testing was completed, four 6-in. x 12-in. cylinders and four 6-in. x 6-in. x 21-in. beams were manufactured from each concrete mixture using appropriate plastic molds. Cylinders and beams were extruded from their molds approximately $24 \mathrm{hr}$ after batching and were stored in either a $100 \%$ humidity concrete curing room (cylinders) or a lime-water bath (beams) of appropriate temperature according to ASTM specifications. A single cylinder and single beam from each batch were tested at 3, 7, 14, and 28 days according to ASTM C39 and ASTM C78 standards. 


\section{Results}

\subsection{Aggregate testing results}

Final and processed data for aggregate testing are shown and discussed in this chapter. Raw data test results are included in Appendix A. Results from ASTM C136 for each aggregate are shown in Figures 1 through 4. Two samples were tested for each aggregate. Of the materials tested, the \#57 and sand aggregates met their respective specified gradation requirements. The 1.5-in. aggregate did not meet one of the five size fraction requirements, and the Product 1 aggregate was dissimilar to any standard concrete aggregate size.

According to ASTM C33 (Standard Specification for Concrete Aggregates), the 1.5-in. material was most similar to a \#467 aggregate. This aggregate size is constrained by 100\% passing 2 in., 95-100\% passing 1.5 in., 35-70\% passing 0.75 in., $10-30 \%$ passing 0.375 in., and $0-5 \%$ passing No. 4. Results for the 1.5-in material are given in Figure 1. This material met all gradation requirements for a \#467 aggregate except for $35-70 \%$ passing $0.75 \mathrm{in}$. For both samples, this aggregate was out of tolerance on this sieve size by an average of $2.43 \%$, on the high side. The material was $100 \%$ passing on the 1.5 -in. sieve and $92 \%$ passing on the 1in. sieve. This would indicate that the nominal maximum size is $1 \mathrm{in}$.

Figure 1. ASTM C136 results for 1.5-in. aggregate.

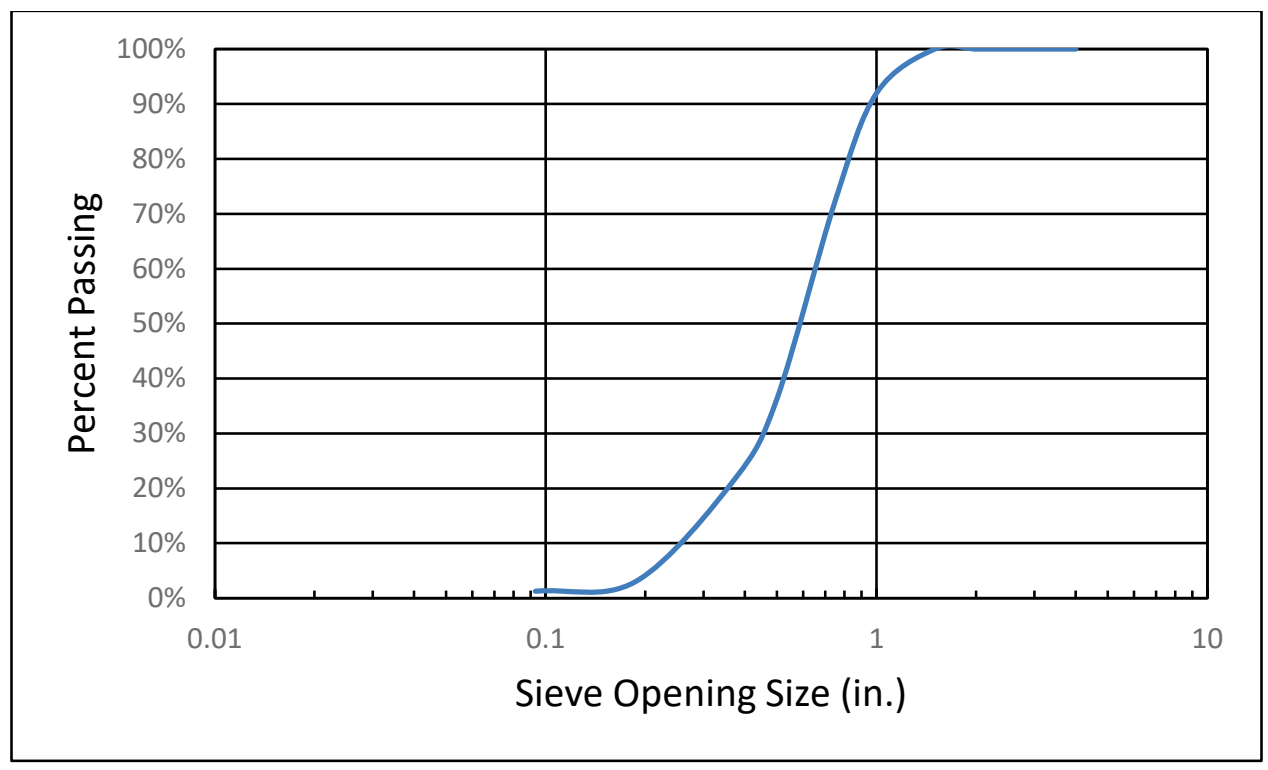


A \#57 material is required by ASTM C33 to meet the size requirements of $100 \%$ passing 1.5 in., $95-100 \%$ passing the 1 in., $25-60 \%$ passing 0.5 in., o$10 \%$ passing No. 4, and 0-5\% passing No. 8. Results for the \# 57 material are given in Figure 2. The tested material met all requirements on both samples.

Figure 2. ASTM C136 results for \#57 aggregate.

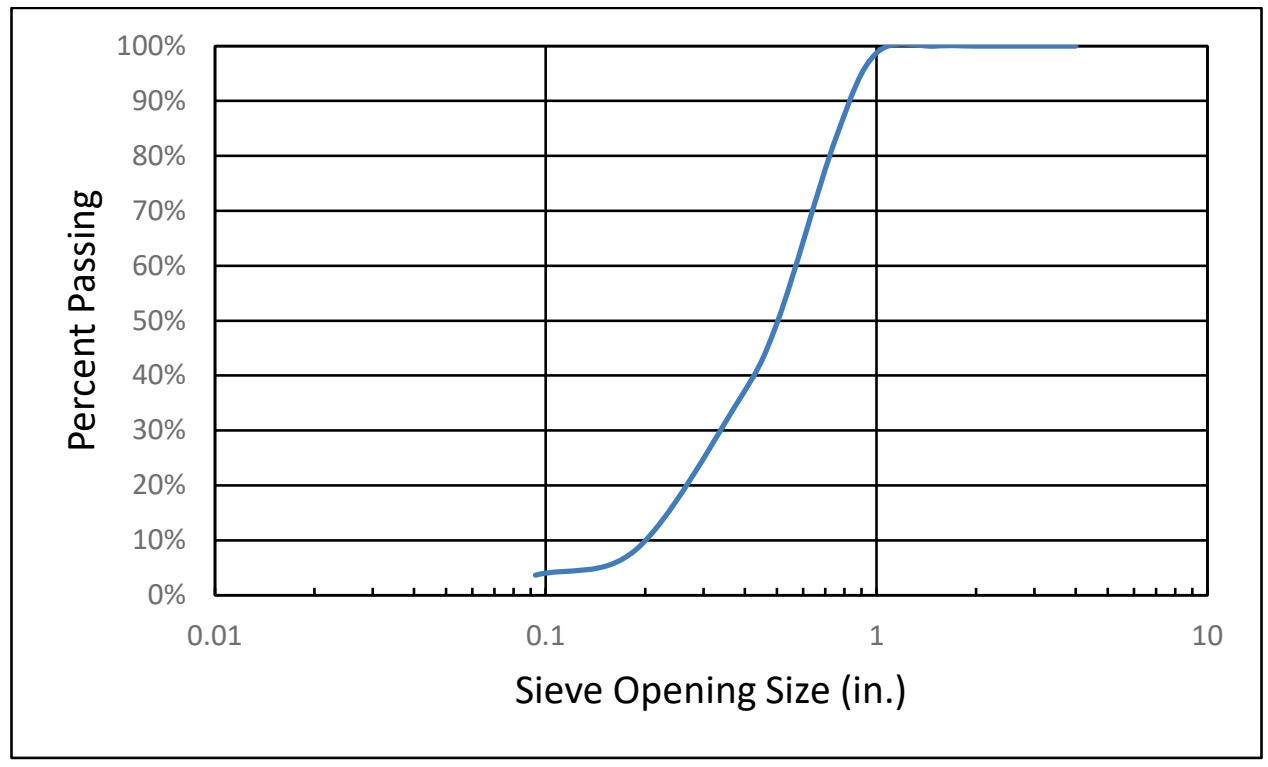

The aggregate "Product 1" was unknown but appeared to be an intermediate size aggregate. Results for the "Product 1" material are given in Figure 3. ASTM C136 results showed that this material did not meet the requirements of any concrete aggregate listed in ASTM C33. The most similar standard size material appeared to be a size \#89, in which the material met three of the six gradation requirements for that size. Results for the sand aggregate material are given in Figure 4. The sand tested met all ASTM C33 requirements for a standard concrete fine aggregate. 
Figure 3. ASTM C136 results for Product 1 aggregate.

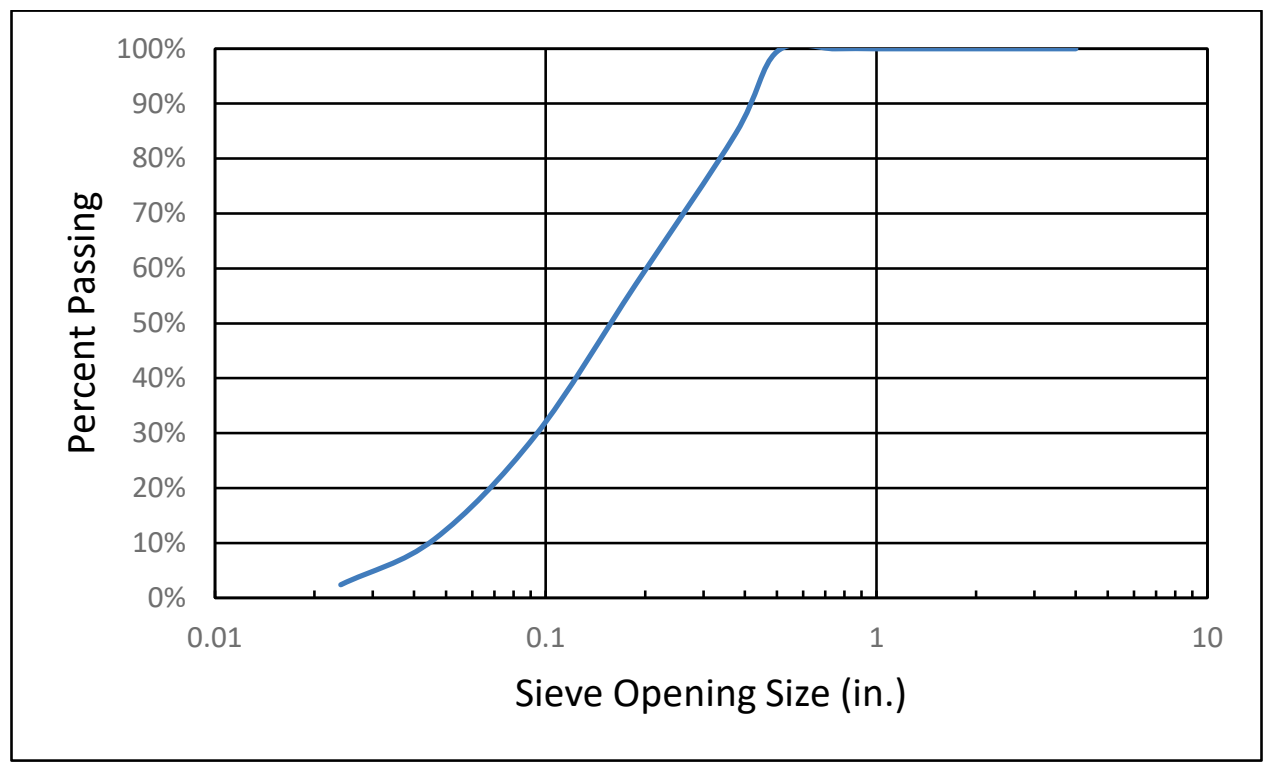

Figure 4. ASTM C136 results for sand aggregate.

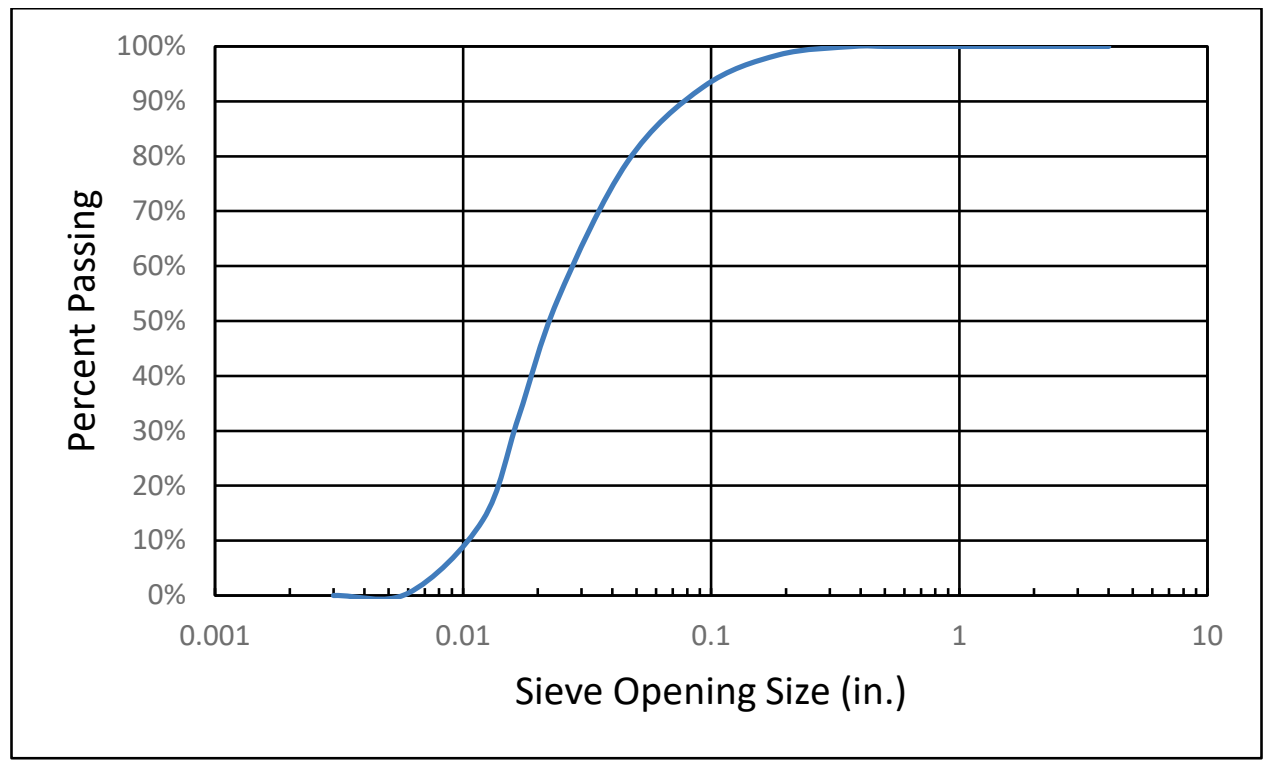

Results from ASTM C117 are shown in Table 3. The average value represents the percentage of material finer than the No. 200 sieve $(75 \mu \mathrm{m})$. The results indicate a normal to slightly low percent finer than No. 200 for the sand, and a normal to slightly high percent finer than No. 200 for the coarse and intermediate aggregates. Results from ASTM C127 and ASTM C128 are shown in Table 4. No outliers or abnormal percentage of fines was recorded for any of the materials tested. 
Table 3. ASTM C117 results.

\begin{tabular}{|l|l|l|l|}
\hline Material & Sample 1 & Sample 2 & Average \\
\hline 1.5 in. & $0.87 \%$ & $0.90 \%$ & $0.9 \%$ \\
\hline$\# 57$ & $1.36 \%$ & $1.51 \%$ & $1.4 \%$ \\
\hline Product 1 & $0.91 \%$ & $0.90 \%$ & $0.9 \%$ \\
\hline Sand & $0.19 \%$ & $0.13 \%$ & $0.2 \%$ \\
\hline
\end{tabular}

Table 4. ASTM C127 and ASTM C128 test results.

\begin{tabular}{|l|l|l|l|l|}
\hline & 1.5 in. & $\# 57$ & Product 1 & Sand \\
\hline Relative Density - OD & 2.59 & 2.63 & 2.61 & 2.61 \\
\hline Relative Density - SSD & 2.60 & 2.63 & 2.62 & 2.62 \\
\hline Relative Density - Apparent & 2.61 & 2.65 & 2.64 & 2.64 \\
\hline Absorption & $0.4 \%$ & $0.3 \%$ & $0.4 \%$ & $0.4 \%$ \\
\hline
\end{tabular}

\subsection{Combined aggregate testing results}

A combined aggregate gradation was determined based on the specific mix design parameters listed in Table 1 . Table 5 gives the results of the combined aggregate gradation. A combined percent retained chart was created and is shown in Figure 5. Each point on the percent retained curve designates a sieve size. Combined aggregate gradations were used in determining the power 45 curve (Figure 6 ) and coarseness and workability factors.

The combined percent retained showed an area of gradation between the No. 4 and No. 30 sieves in which there were two low points between two peaks. As per the specifications, it was indicated that there should be no more than one low point between two peaks.

The combined gradation curve (Figure 6) appears to stay within the upper and lower boundary with the exception of material smaller than the No. 30 sieve. This is generally normal for concrete mixtures to allow space for the paste portion. The gradation curve does approach the upper boundary from sizes No. 16 to No. 8 and again from 0.75 in. to 1 in. 
Table 5. Combined Aggregate Gradation.

\begin{tabular}{|l|l|l|l|}
\hline Sieve Size & $\begin{array}{c}\text { Individual \% } \\
\text { Ret }\end{array}$ & $\begin{array}{c}\text { Cumulative } \% \\
\text { Ret }\end{array}$ & $\begin{array}{c}\text { Cumulative } \% \\
\text { Passing }\end{array}$ \\
\hline 4 in. & $0.00 \%$ & $0.00 \%$ & $100.00 \%$ \\
\hline 3.5 in. & $0.00 \%$ & $0.00 \%$ & $100.00 \%$ \\
\hline 3 in. & $0.00 \%$ & $0.00 \%$ & $100.00 \%$ \\
\hline 2.5 in. & $0.00 \%$ & $0.00 \%$ & $100.00 \%$ \\
\hline 2 in. & $0.00 \%$ & $0.00 \%$ & $100.00 \%$ \\
\hline 1.5 in. & $0.00 \%$ & $0.00 \%$ & $100.00 \%$ \\
\hline 1 in. & $2.34 \%$ & $2.34 \%$ & $97.66 \%$ \\
\hline 0.75 in. & $10.06 \%$ & $12.40 \%$ & $87.60 \%$ \\
\hline 0.5 in. & $20.07 \%$ & $32.48 \%$ & $67.52 \%$ \\
\hline 0.375 in. & $10.50 \%$ & $42.98 \%$ & $57.02 \%$ \\
\hline No. 4 & $17.50 \%$ & $60.48 \%$ & $39.52 \%$ \\
\hline No. 8 & $7.26 \%$ & $67.74 \%$ & $32.26 \%$ \\
\hline No. 16 & $7.96 \%$ & $75.70 \%$ & $24.30 \%$ \\
\hline No. 30 & $8.39 \%$ & $84.09 \%$ & $15.91 \%$ \\
\hline No. 40 & $6.50 \%$ & $90.60 \%$ & $9.40 \%$ \\
\hline No. 50 & $5.42 \%$ & $96.02 \%$ & $3.98 \%$ \\
\hline No. 100 & $3.86 \%$ & $99.88 \%$ & $0.12 \%$ \\
\hline No. 200 & $0.12 \%$ & $100.00 \%$ & $0.00 \%$ \\
\hline
\end{tabular}

Figure 5. Combined percent retained by sieve size.

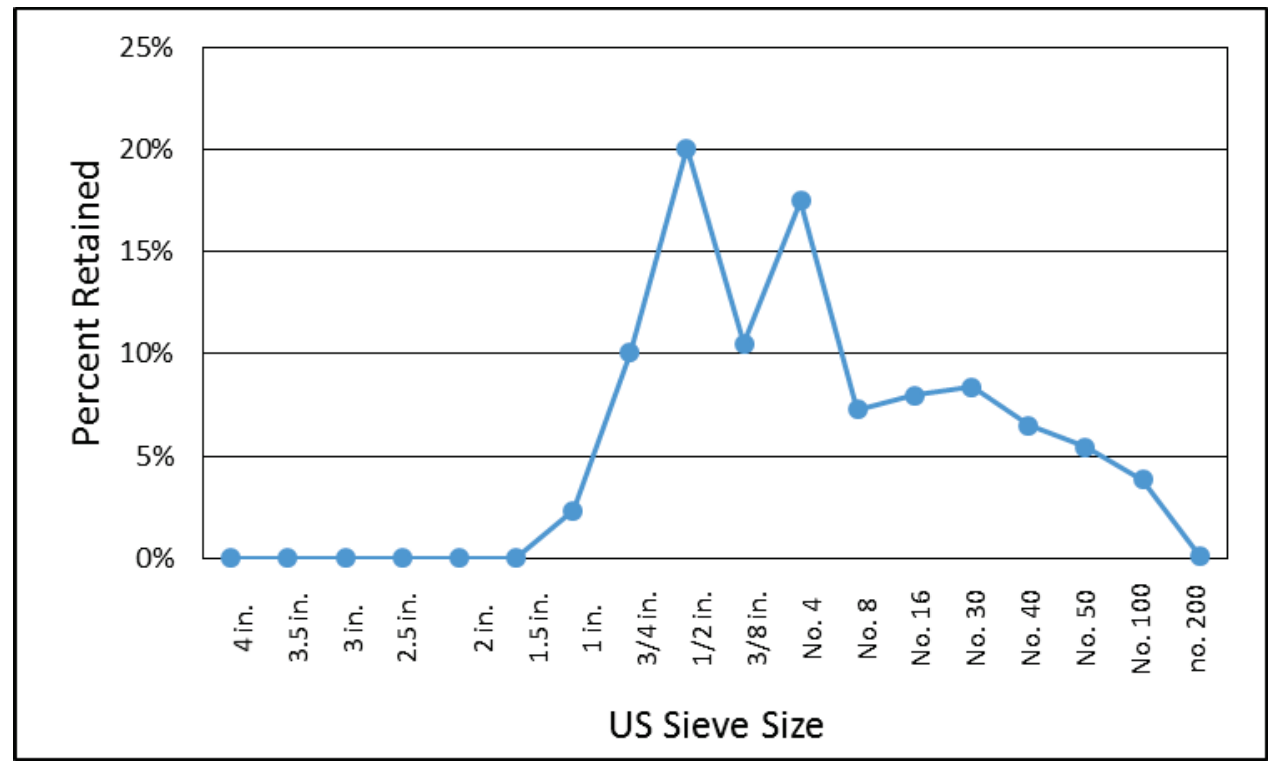


Figure 6. Power 45 chart.

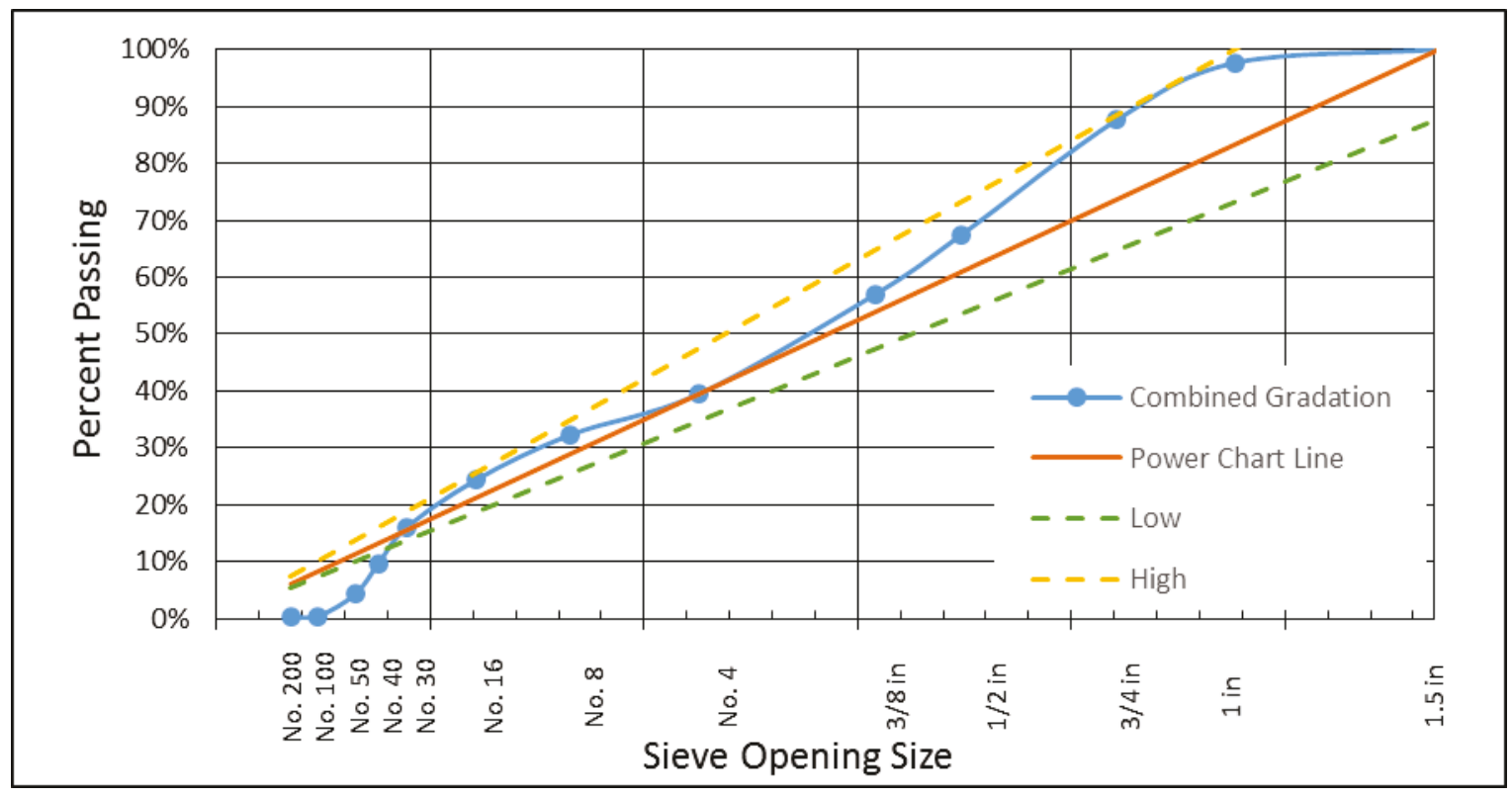

The coarseness factor (CF) and workability factor (WF) for the combined aggregate gradation were determined using equations 1 and 2. Calculated values were 63.45 for $\mathrm{CF}$ and 33.51 for WF. Figure 7 illustrates the calculated $\mathrm{CF}$ versus $\mathrm{WF}$ factor and the target limits described in the specifications. As seen in the figure, the calculated values fell within the prescribed limits.

$$
C F=\frac{\text { cumulative } \% \text { retained on } \frac{3}{8} \text {-in sieve }}{\text { cumulative } \% \text { retained on } N o .8 \text { sieve }} * 100
$$

$W F=($ cumulative $\%$ passing No.8 sieve $)+2.5 * \frac{\text { cementitious content }-564}{94}$ 
Figure 7. Calculated CF versus WF with limits shown.

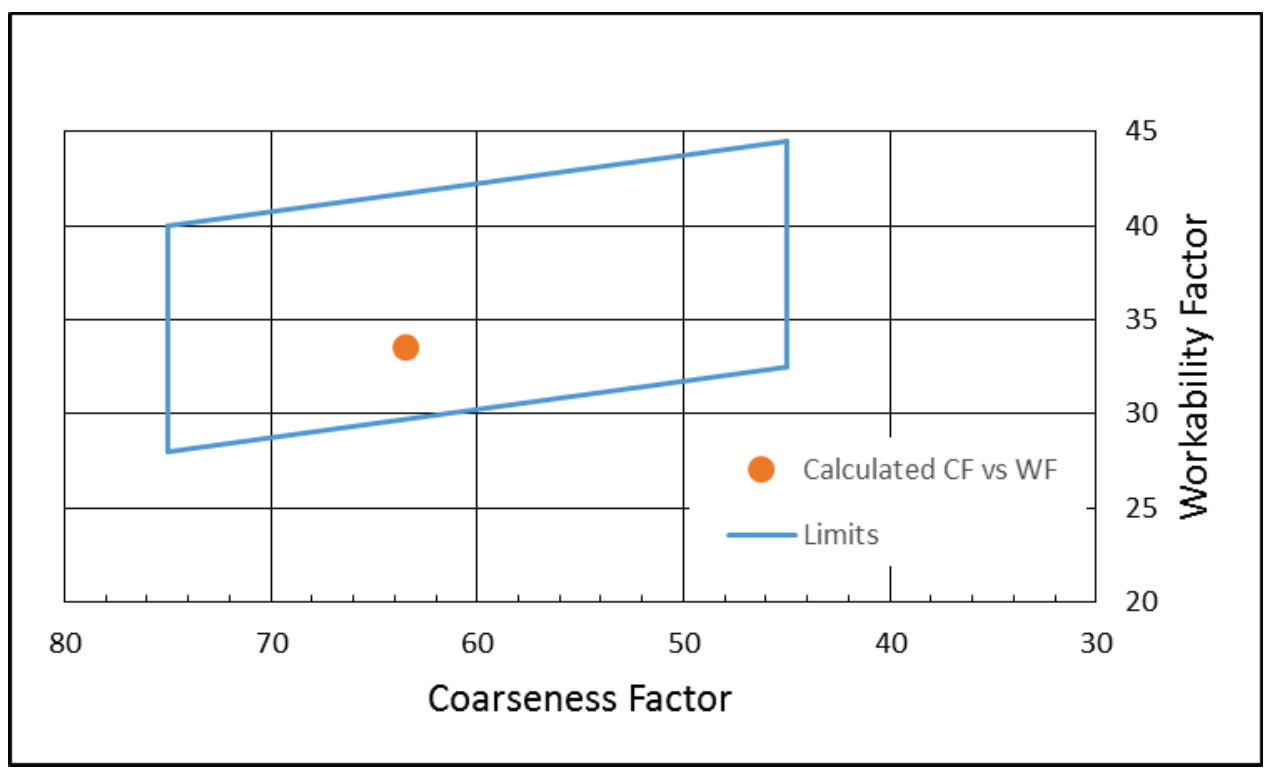

\subsection{Concrete mixture design results}

Final and reduced data for concrete testing is shown and discussed in this section. Raw data test results are included in Appendix B. Moisture contents of the materials at the time of batching were $0.22 \%, 0.37 \%$, 3.40\% and 2.94\% for 1.5-in., \# 57, "Product 1," and sand materials, respectively. Batch quantities were adjusted for moisture contents to ensure consistency with field mixtures. Fresh concrete properties are shown in Table 6 for each mixture. Target fresh properties were slump of $0-2$ in., unit weight of $143.1 \mathrm{lb} / \mathrm{ft}^{3}$, and air content of $6 \% \pm 1.5 \%$. Values were rounded to either the nearest quarter inch (slump) or the nearest tenth (unit weight, air content, temperature).

Table 6. Fresh mixed concrete properties.

\begin{tabular}{|l|c|c|c|c|}
\hline & Slump (in.) & $\begin{array}{c}\text { Unit Weight } \\
\left(\mathrm{lb} / \mathrm{ft}^{3}\right)\end{array}$ & Air Content (\%) & Temperature $\left({ }^{\circ} \mathrm{F}\right)$ \\
\hline Batch 1 & 1.00 & 146.0 & 5.8 & 70.6 \\
\hline Batch 2 & 0.25 & 148.4 & 4.8 & 70.2 \\
\hline Batch 3 & 0.25 & 147.2 & 5.1 & 70.3 \\
\hline Average & 0.50 & 147.2 & 5.2 & 70.4 \\
\hline
\end{tabular}

Slump met the specified requirements, but was on the lower half of the targeted values. Unit weight values were $2.9 \%$ higher than the theoretical calculated values for the mixture. Air contents were within specified tolerances, but were $1.3 \%$ lower, on average, than the target air content. 
Temperature met the requirements outlined in standard ASTM specifications for laboratory mixed concrete.

Based on visual inspection immediately after mixing, the concrete appeared to be stiff or "boney." This was expected as recent studies by the Federal Highways Administration have noted that mixtures adhering closely to the maximum density line of the power 45 chart can be dense and difficult to work (FHWA-HIF-15-019, 2015). Cylinders and beams were vibrated to consolidate the mixture, and it was noted that the vibratory process took longer than for most concrete mixtures, and even with a longer vibration period there were still a large number of unclosed spaces and voids in the finished specimens. Figure 8 illustrates the unclosed holes in final specimens.

Figure 8. Specimen photos illustrating unclosed holes.

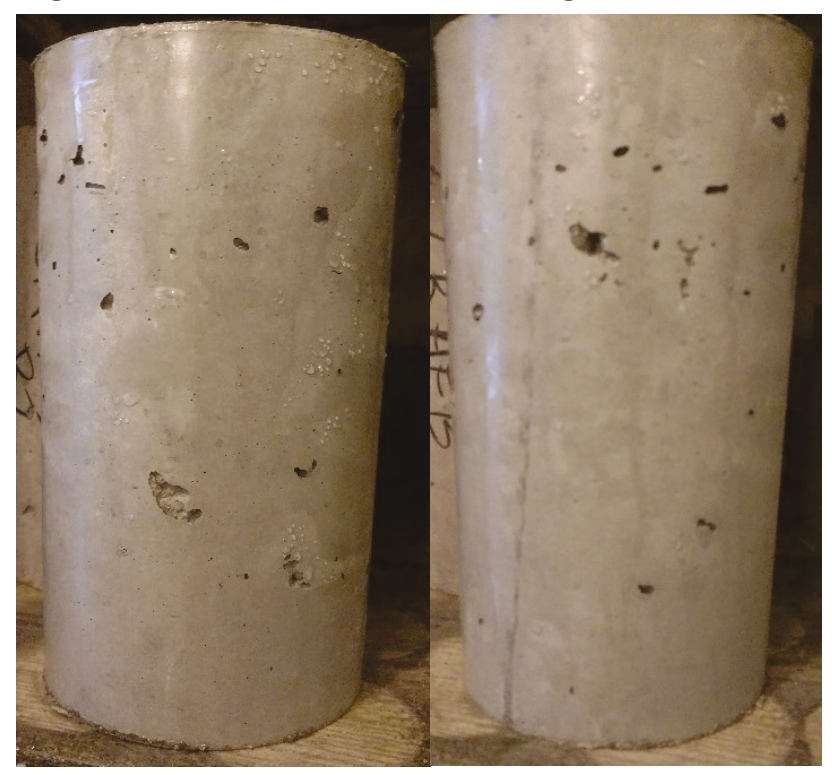

Table 7 and Table 8 show results for the flexural strength and compressive strength testing, respectively. A single specimen from each batch was tested at each test day so that the average results represent the average of one specimen each from three batches. Coefficients of variation (CoVs) are also included in the tables for statistical validation. The specification prescribed a flexural strength of 650 psi at 28 days. Based on the results from these tables, the mixture achieved sufficient flexural strength by seven days. Averages and $\mathrm{CoV}$ values show a good level of agreement between batches. 
Table 7. Flexural strength results.

\begin{tabular}{|l|l|l|l|l|}
\hline & 3 Day & 7 Day & 14 Day & 28 Day \\
\hline Batch 1 (psi) & 619 & 645 & 745 & 845 \\
\hline Batch 2 (psi) & 615 & 675 & 720 & 970 \\
\hline Batch 3 (psi) & 610 & 715 & 790 & 930 \\
\hline Average (psi) & 615 & 678 & 752 & 915 \\
\hline CoV (\%) & 0.6 & 4.2 & 3.9 & 5.7 \\
\hline
\end{tabular}

Table 8. Compressive strength results (psi).

\begin{tabular}{|l|l|l|l|l|}
\hline & 3 Day & 7 Day & 14 Day & 28 Day \\
\hline Mixture 1 & $---*$ & 4350 & 4980 & 5510 \\
\hline Mixture 2 & 4490 & 4610 & 5460 & 6010 \\
\hline Mixture 3 & 4010 & 4400 & 5220 & 5900 \\
\hline Average & 4250 & 4453 & 5220 & 5807 \\
\hline CoV & 5.7 & 2.5 & 3.8 & 3.7 \\
\hline
\end{tabular}

*Cylinder break was non-traditional and was excluded from average. 


\section{Summary and Conclusions}

\subsection{Summary}

Of the coarse aggregate materials, the \#57 material met all requirements of ASTM C33 for a \#57 aggregate. The 1.5-in. aggregate was similar to a \#467 material, meeting all but one of the five gradation requirements. As the "Product 1" aggregate was most similar to a \#89 material but met only three of the six gradation requirements for a size \#89, the "Product 1 " material did not fit into any size category described in ASTM C33.

Specifications stated a coarse aggregate nominal maximum aggregate size of $1.5 \mathrm{in}$. However, based on testing contained in this report, the nominal maximum aggregate size was 1 in. The combined aggregate gradation met the requirements of the 45 power chart but was frequently at the maximum upper end of the limit. The gradation was within the limits of the coarseness versus workability factors.

The concrete mixture met the slump and air content tolerances as specified, but the air content was $1.3 \%$ lower, on average, than the target. Measured unit weight was $2.9 \%$ higher than theoretical. Visually, the mixture appeared stiff, or "boney," and was difficult to finish. The mixture was difficult to work into molds and had to be vibrated longer than usual to consolidate.

On average, hardened concrete properties of compressive and flexural strength met 28 day specification guidelines at 7 days.

\subsection{Conclusions}

In general, there were some discrepancies in the coarse aggregate materials, such as not fitting into ASTM C33 gradation categories and the actual nominal maximum aggregate size being lower than specified. However, the combined gradation was able to achieve the prescribed power 45 and workability versus coarseness requirements. Fresh mixed concrete properties of slump and air content and hardened properties of compressive and flexural strength also met the requirements outlined.

Despite meeting the tested concrete performance properties, the mixture was difficult to finish and consolidate. Definitive conclusions on mixture 
design performance are not obtainable from this study as only a portion of the specified requirements were evaluated. However, the mixture design did meet all of the combined gradation, fresh mixed concrete properties, and hardened concrete properties that were selected for testing. 


\section{Contact Information}

Permission to publish was granted by the Director, Geotechnical and Structures Laboratory. For questions related to this investigation, contact

Jameson "Jay" D. Shannon

Geotechnical and Structures Laboratory

U.S. Army Engineer Research and Development Center

Office: 601.634.2218 / Email: Jameson.Shannon@usace.army.mil

Mail: 3909 Halls Ferry Rd., Attn: CEERD-GMC, Vicksburg, MS 39180. 


\section{References}

American Society of Testing and Materials (ASTM). 2013. Standard test method for materials finer than 75- $\mu$ m (No. 200) sieve in mineral aggregates by washing. Designation: C117-13. West Conshohocken, PA: ASTM International.

2014. Standard test method for sieve analysis of fine and coarse aggregates. Designation: ASTM C136/C136M-14. West Conshohocken, PA: ASTM International.

. 2015a. Standard test method for relative density (specific gravity) and absorption of coarse aggregate. Designation: ASTM C127-15. West Conshohocken, PA: ASTM International.

2015b. Standard test method for relative density (specific gravity) and absorption of fine aggregate. Designation: ASTM C128-15. West Conshohocken, PA: ASTM International.

. 2015c. Standard test method for slump of hydraulic-cement concrete. Designation: ASTM C143/C143M-15a. West Conshohocken, PA: ASTM International.

. 2016a. Standard practice for making and curing concrete test specimens in the laboratory. Designation: ASTM C192/C192M-16a. West Conshohocken, PA: ASTM International.

. 2016b. Standard specification for concrete aggregates. Designation: C33/C33M-16c1. West Conshohocken, PA: ASTM International.

2016c. Standard test method for flexural strength of concrete (using simple beam with third-point loading). ASTM C78/C78M-16. West Conshohocken, PA: ASTM International.

. 2016d. Standard test method for organic impurities in fine aggregates for concrete. Designation: ASTM C40/C40M-16. West Conshohocken, PA: ASTM International.

. 2017a. Standard test method for air content of freshly mixed concrete by the pressure method. Designation: ASTM C231/C231M-17a. West Conshohocken, PA: ASTM International.

2017b. Standard test method for compressive strength of cylindrical concrete specimens. Designation: ASTM C39/C39M-17a. West Conshohocken, PA: ASTM International.

. 2017c. Standard test method for density (unit weight), yield, and air content (gravimetric) of concrete. Designation: ASTM C138/C138M-17a. West Conshohocken, PA: ASTM International.

Federal Highway Administration (FHWA). 2015. Blended aggregates for concrete mixture optimization - best practices for jointed concrete pavements. FHWAHIF-15-019. Washington, DC: FHWA. 


\section{Appendix A: Raw Data Sheets for Aggregate Testing}

Table A1. ASTM C127 for 1.5-in. aggregate.

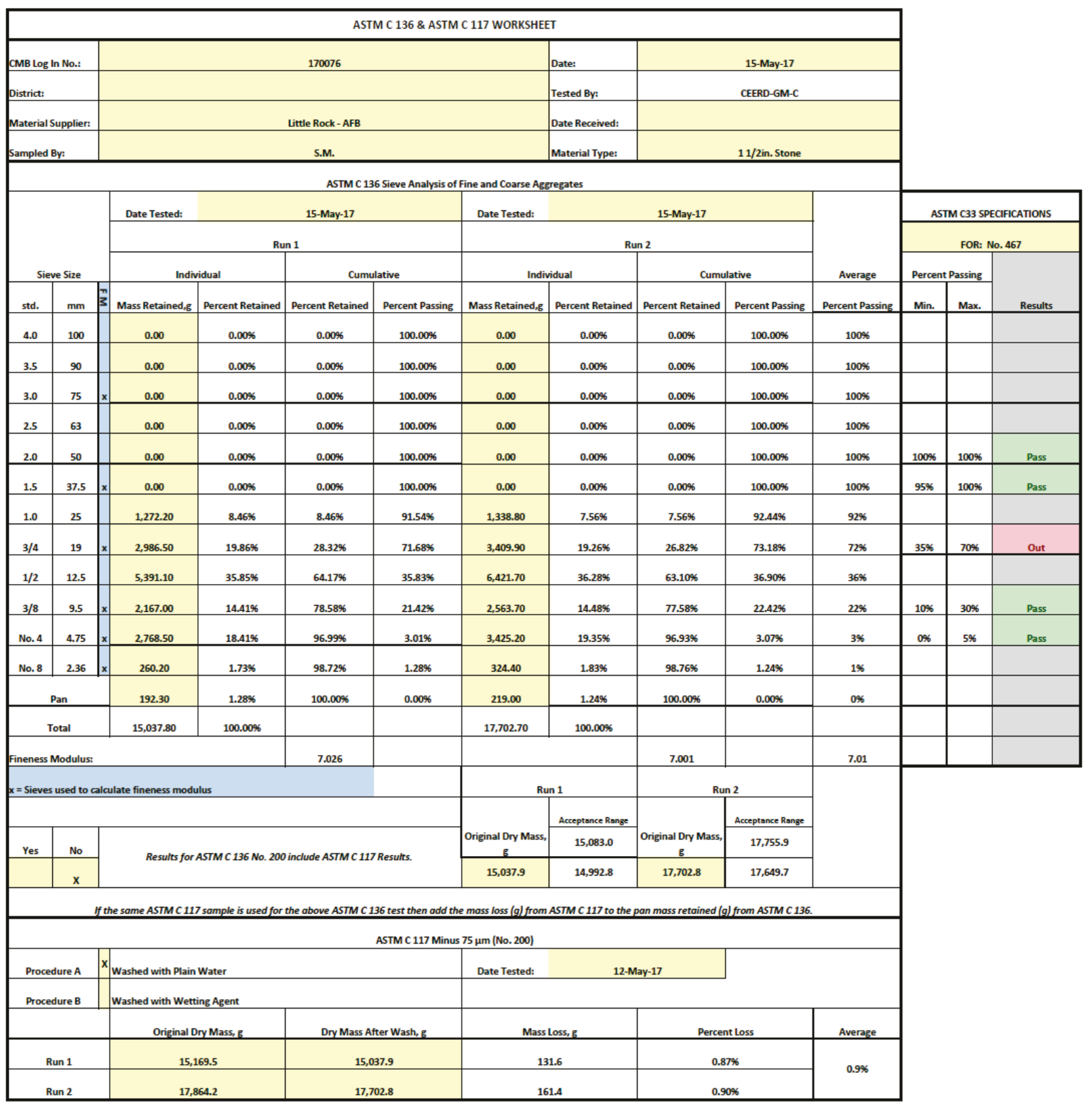


Table A2. ASTM C127 for 1.5-in. aggregate.
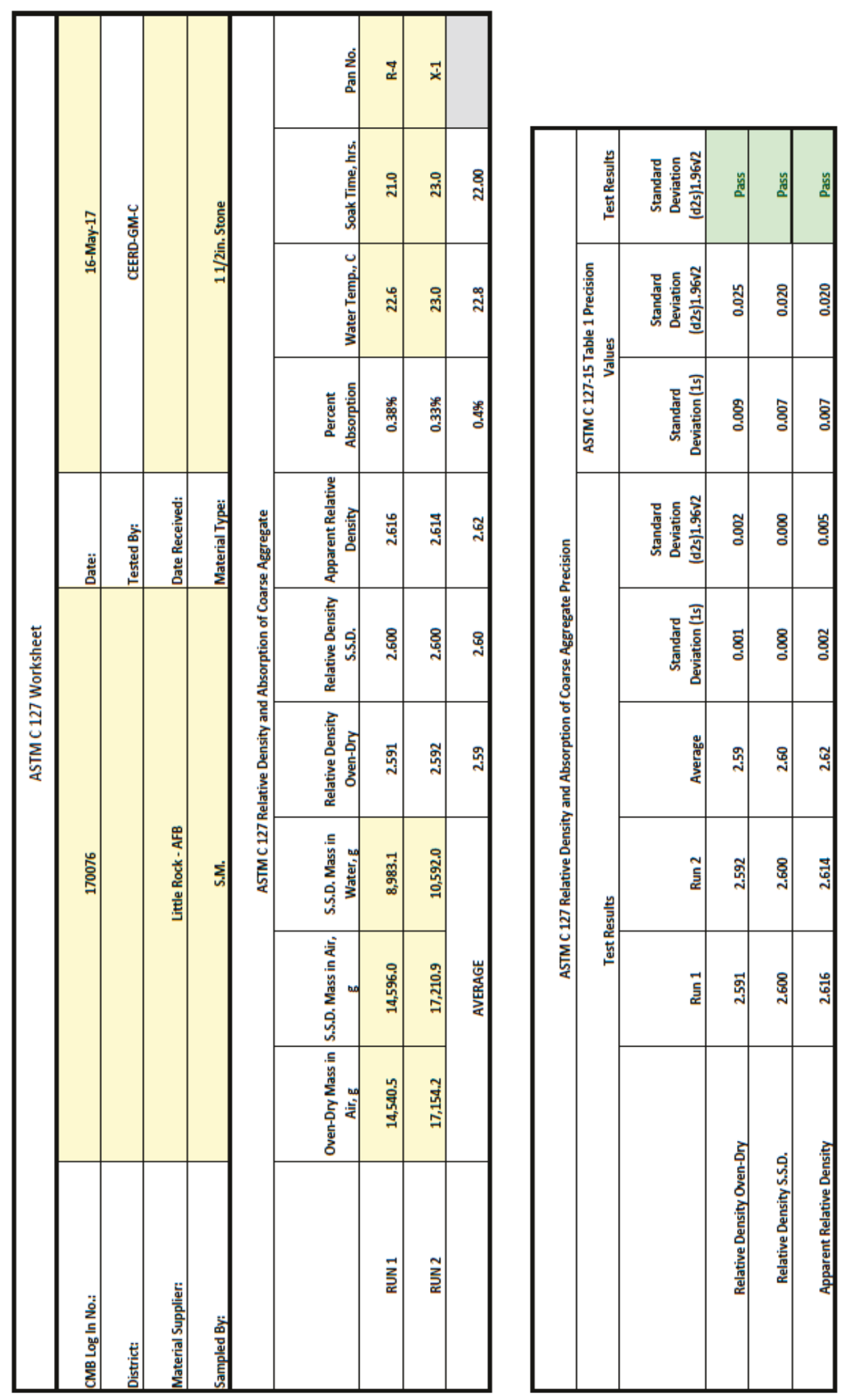
Table A3. ASTM C136 and ASTM C117 precision for 1.5-in. aggregate.

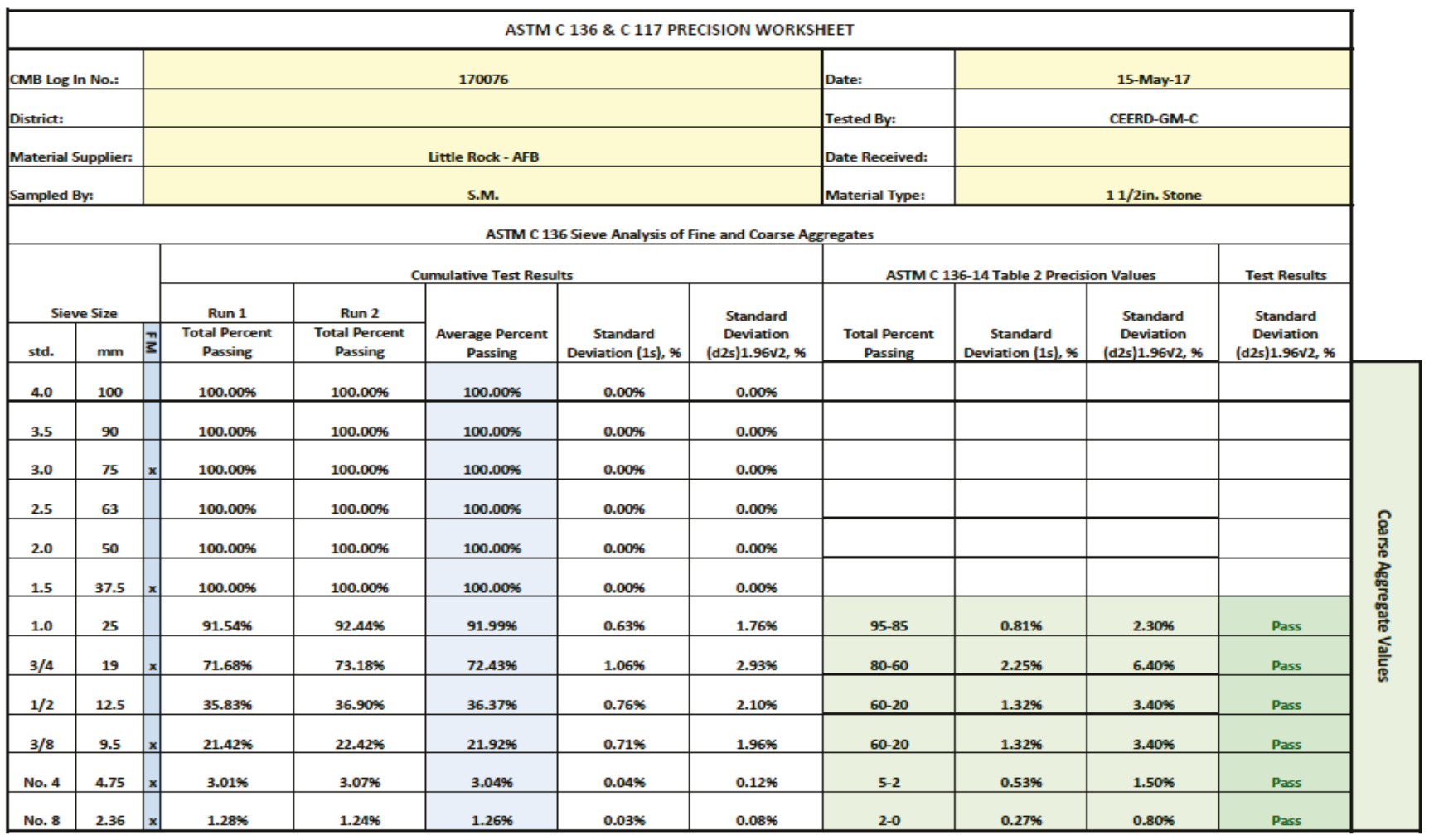

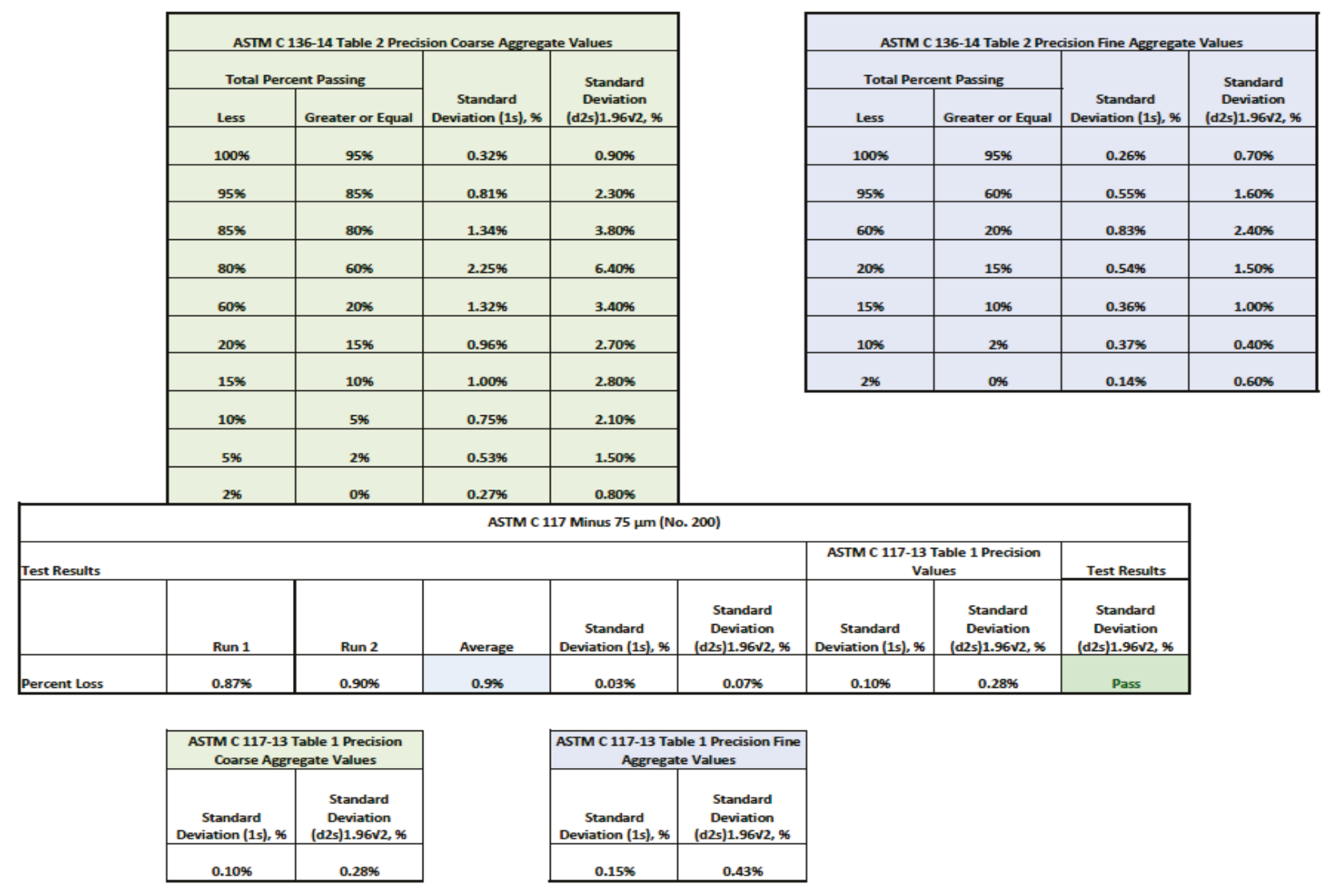


Table A4. ASTM C136 and ASTM C117 for \#57 aggregate.

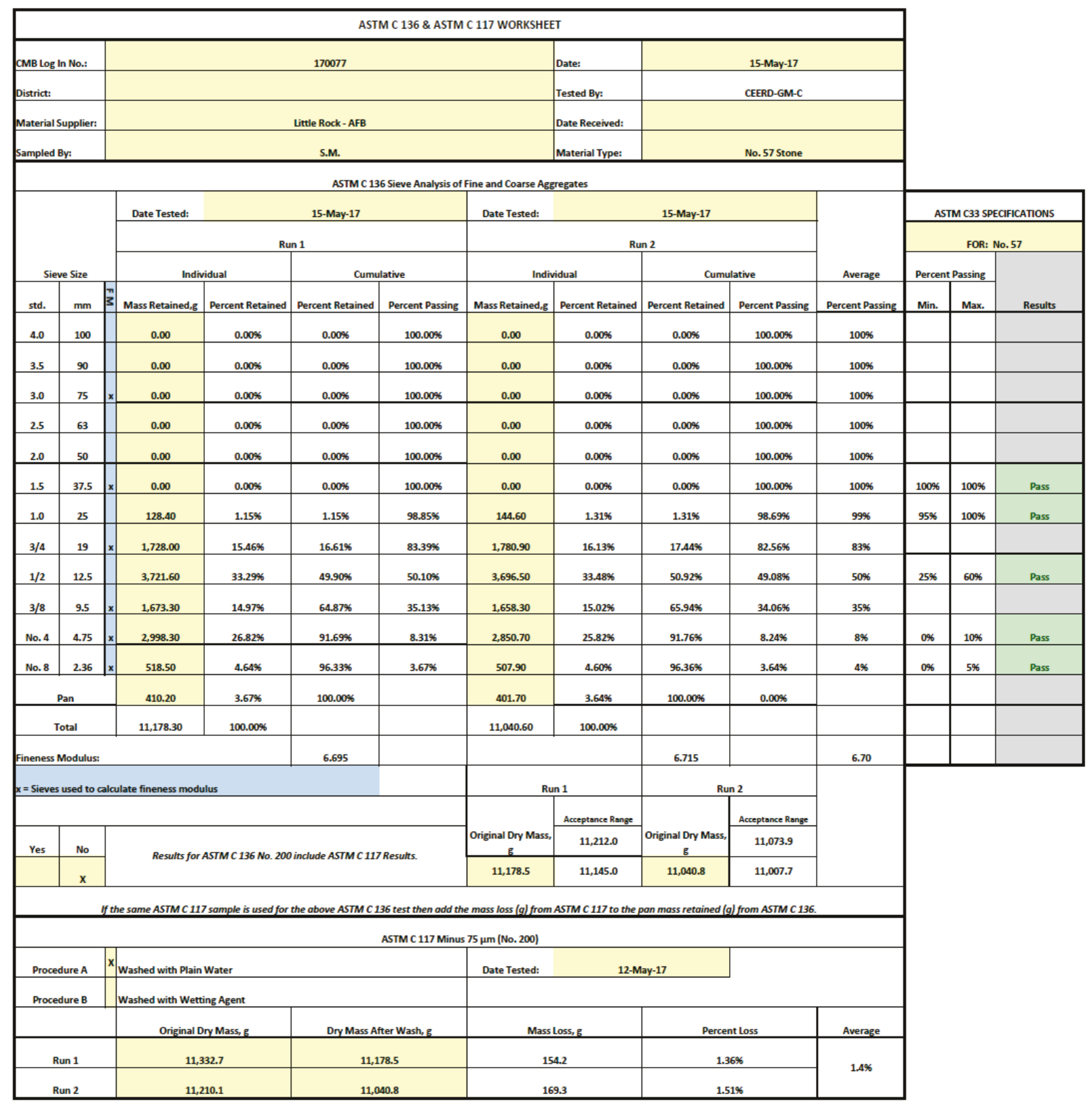


Table A5. ASTM C127 for \#57 aggregate.
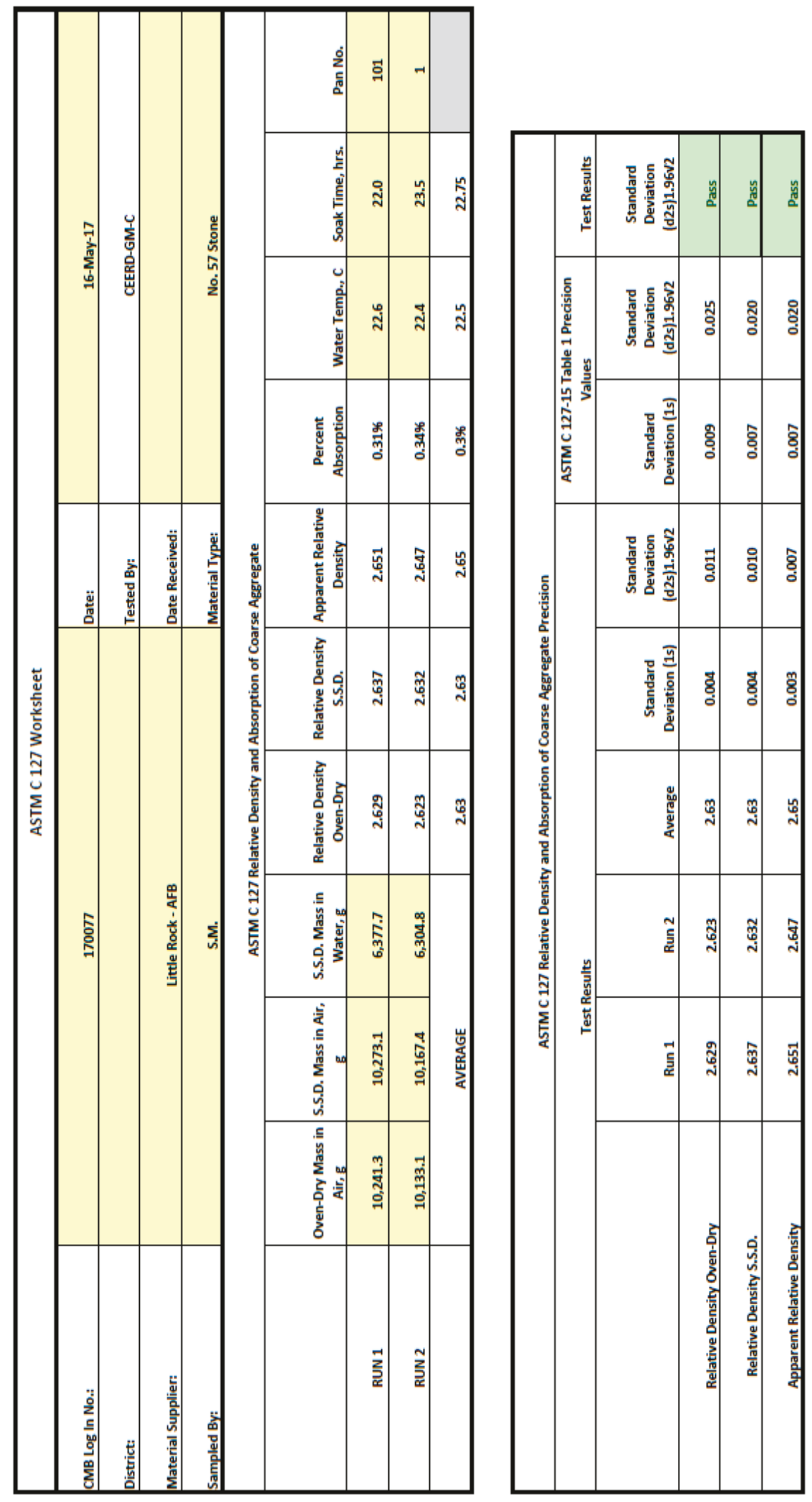
Table A6. ASTM C136 and C137 precision for \#57 aggregate.

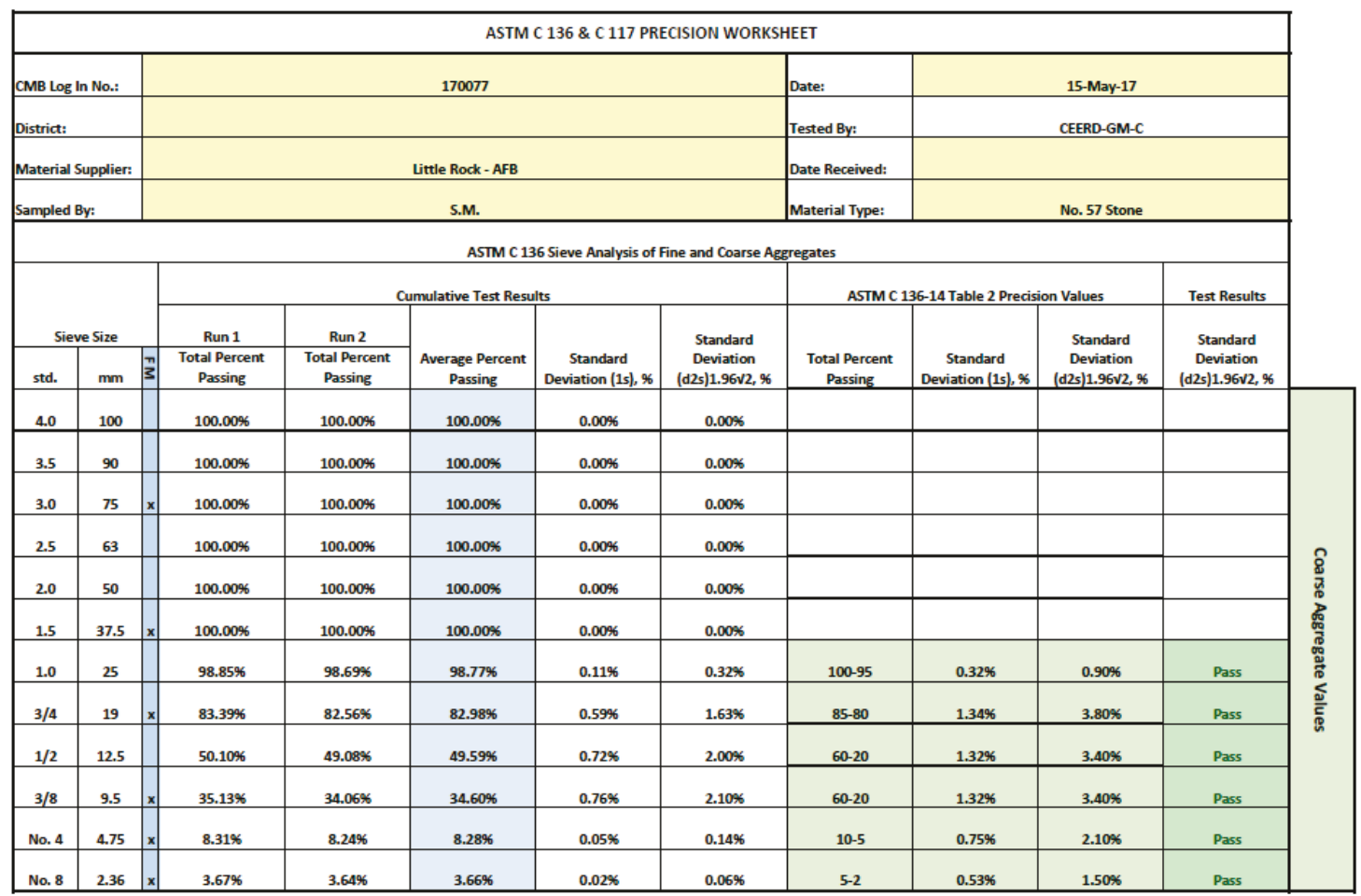

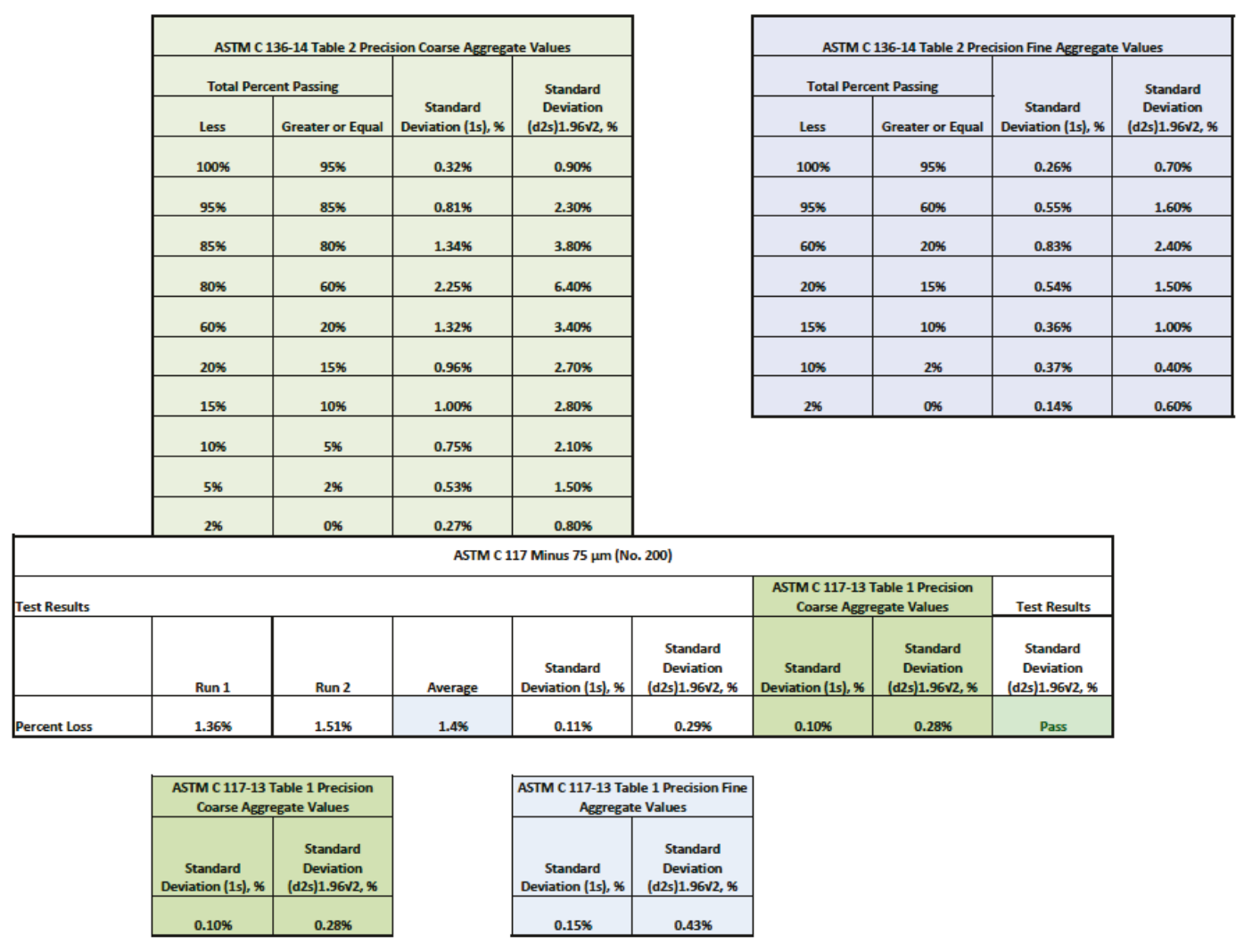


Table A7. ASTM C137 and C137 for Product 1 aggregate.

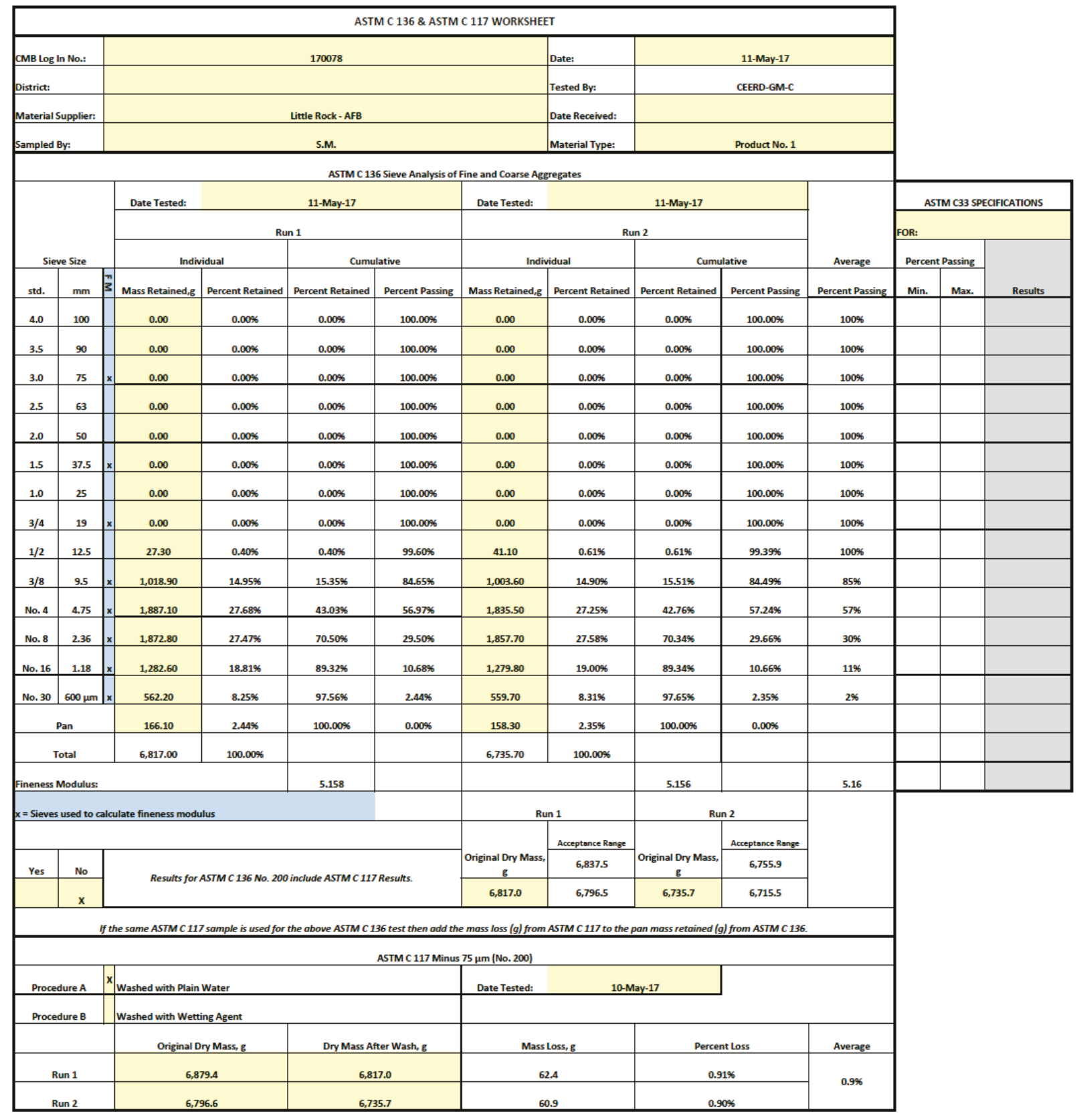


Table A8. ASTM C127 and ASTM C128 for Product 1 aggregate.
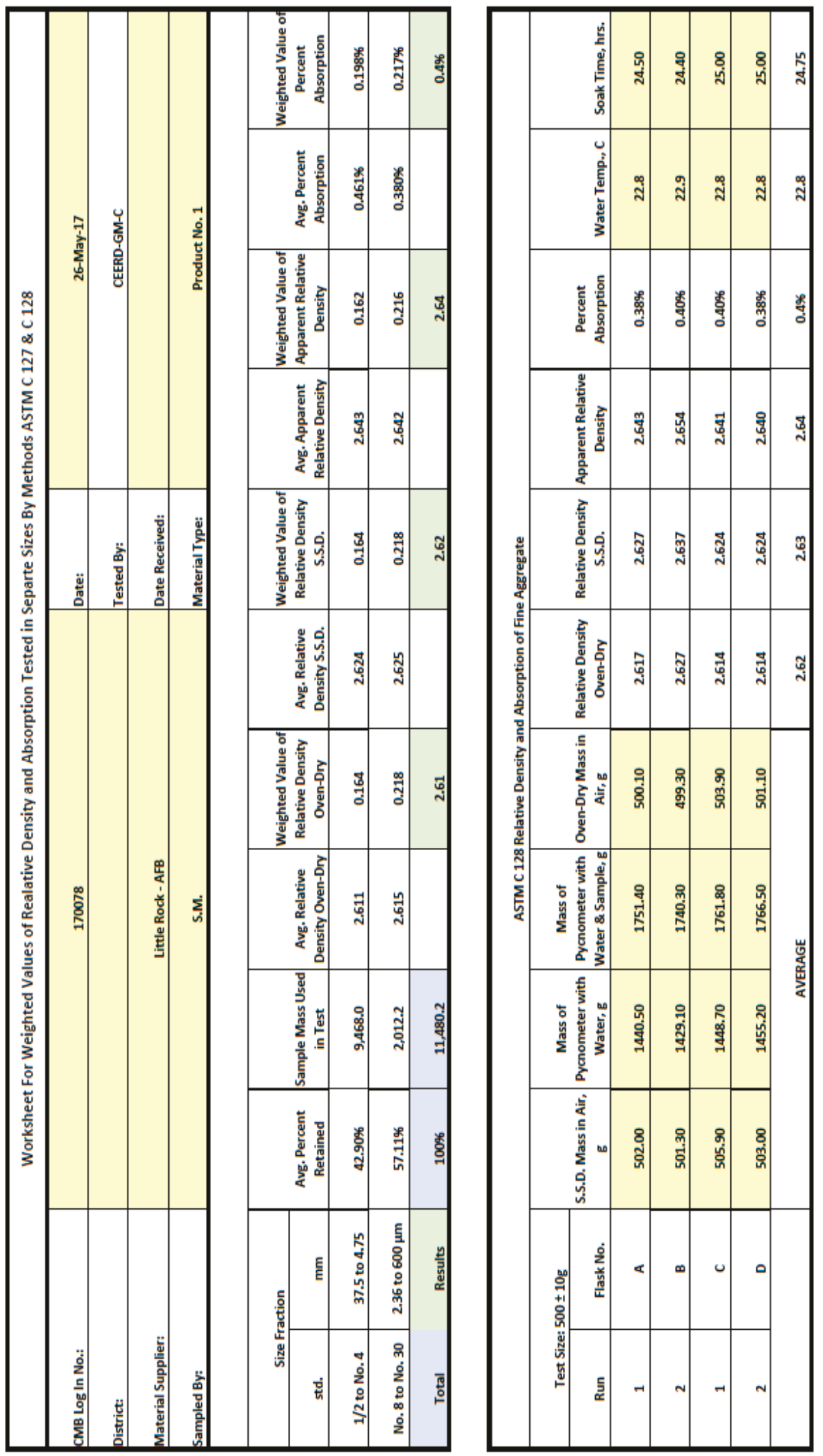
Table A9. ASTM C128 for Product 1 aggregate.
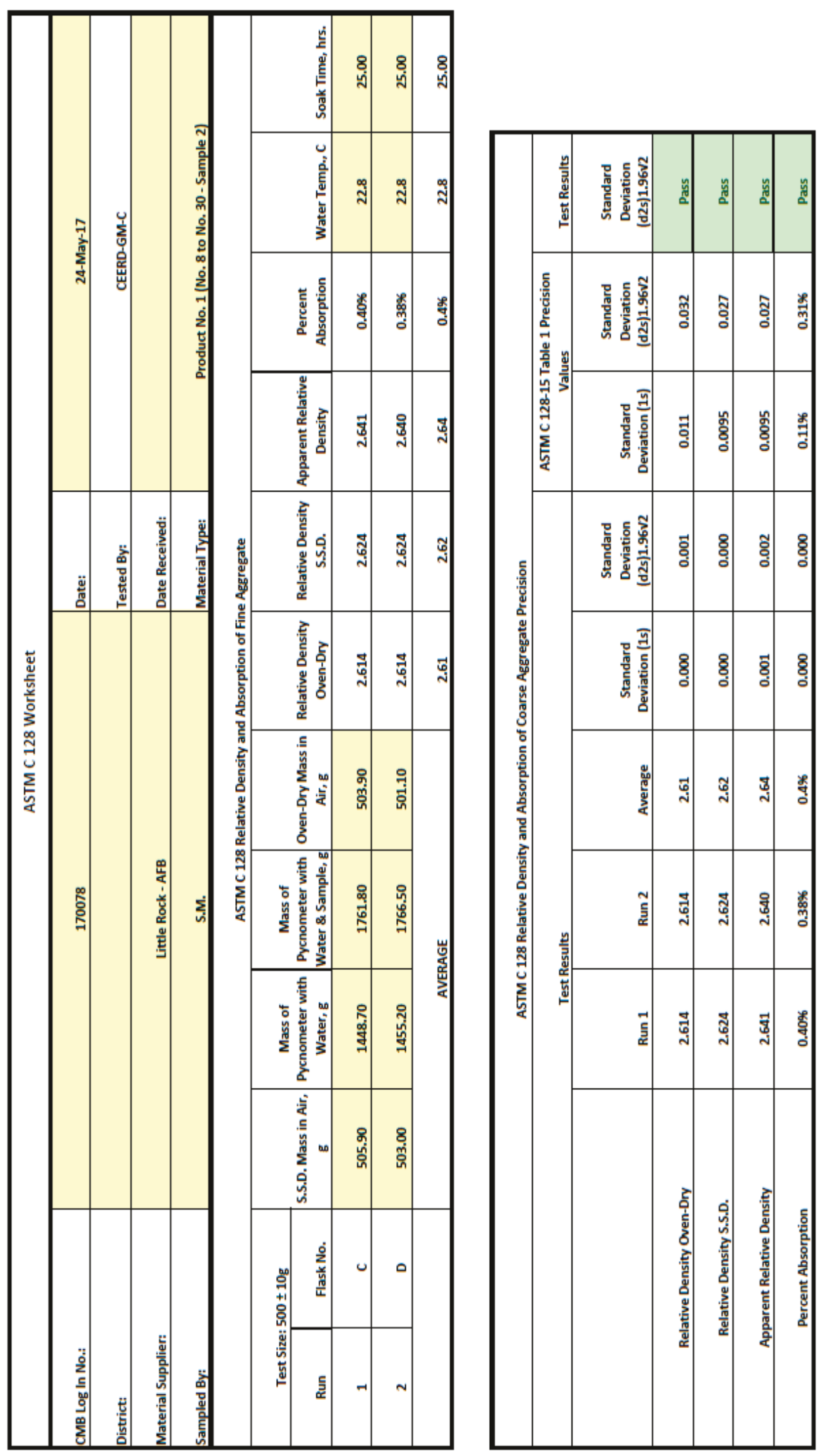
Table A10. ASTM C136 and C117 precision.

\begin{tabular}{|c|c|c|c|c|c|c|c|c|c|c|c|c|}
\hline & & & & & ASTN & 1 C 136 \& C 117 PRE & ECISION WORKSHE & HEET & & & & \\
\hline CMB $\log 1$ & No.: & & & & 170078 & & & Date: & & 11-May-17 & & \\
\hline District: & & & & & & & & Tested By: & & CEERD-GM-C & & \\
\hline Material S & upplier: & & & & Little Rock - AFB & & & Date Received: & & & & \\
\hline Sampled $\mathrm{E}$ & & & & & S.M. & & & Material Type: & & Product No. 1 & & \\
\hline & & & & & ASTM C & 136 Sieve Analysis of F & Fine and Coarse Aggre & regates & & & & \\
\hline & & & & & Imulative Test Resu & & & ASTMC & 36-14 Table 2 Precisi & ion Values & Test Results & \\
\hline & e Size & & Run 1 & & & & & & & & & \\
\hline std. & & 3 & $\begin{array}{c}\text { Total Percent } \\
\text { Passing }\end{array}$ & $\begin{array}{c}\text { Total Percent } \\
\text { Passing }\end{array}$ & $\begin{array}{c}\text { Average Percent } \\
\text { Passing }\end{array}$ & \begin{tabular}{|c|} 
Standard Deviation \\
(15), $\%$
\end{tabular} & $\begin{array}{c}\text { Standard Deviation } \\
\text { (d2s)1.96 } 2,96\end{array}$ & $\begin{array}{c}\text { Total Percent } \\
\text { Passing }\end{array}$ & \begin{tabular}{|c|} 
Standard Deviation \\
(1s), $\%$
\end{tabular} & $\begin{array}{c}\text { Standard Deviation } \\
\text { (d2s)1.96v2, \% }\end{array}$ & $\begin{array}{l}\text { Standard Deviation } \\
\text { (d2s)1.96v2, \% }\end{array}$ & \\
\hline 4.0 & 100 & & $100.00 \%$ & $100.00 \%$ & $100.00 \%$ & $0.00 \%$ & $0.00 \%$ & & & & & \\
\hline 3.5 & 90 & & $100.00 \%$ & $100.00 \%$ & $100.00 \%$ & $0.00 \%$ & $0.00 \%$ & & & & & \\
\hline 3.0 & 75 & $\times$ & $100.00 \%$ & $100.00 \%$ & $100.00 \%$ & $0.00 \%$ & $0.00 \%$ & & & & & \\
\hline 2.5 & 63 & & $100.00 \%$ & $100.00 \%$ & $100.00 \%$ & $0.00 \%$ & $0.00 \%$ & & & & & 产 \\
\hline 2.0 & 50 & & $100.00 \%$ & $100.00 \%$ & $100.00 \%$ & $0.00 \%$ & $0.00 \%$ & & & & & 承 \\
\hline 1.5 & 37.5 & $\mathrm{x}$ & $100.00 \%$ & $100.00 \%$ & $100.00 \%$ & $0.00 \%$ & $0.00 \%$ & & & & & 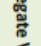 \\
\hline 1.0 & 25 & & $100.00 \%$ & $100.00 \%$ & $100.00 \%$ & $0.00 \%$ & $0.00 \%$ & & & & & 崖 \\
\hline $3 / 4$ & 19 & $\mathbf{x}$ & $100.00 \%$ & $100.00 \%$ & $100.00 \%$ & $0.00 \%$ & $0.00 \%$ & & & & & \\
\hline $1 / 2$ & 12.5 & & $99.60 \%$ & 99.39\% & 99.49\% & $0.15 \%$ & $0.41 \%$ & $100-95$ & $0.32 \%$ & $0.90 \%$ & Pass & \\
\hline $3 / 8$ & 9.5 & $\mathbf{x}$ & $84.65 \%$ & $84.49 \%$ & $84.57 \%$ & $0.12 \%$ & $0.32 \%$ & $95-85$ & $0.81 \%$ & $2.30 \%$ & Pass & \\
\hline №. 4 & 4.75 & $x$ & $56.97 \%$ & $57.24 \%$ & $57.11 \%$ & $0.19 \%$ & $0.53 \%$ & $60-20$ & $0.83 \%$ & $2.40 \%$ & Pass & $\frac{n}{\bar{n}}$ \\
\hline No. 8 & 2.36 & $\mathrm{x}$ & $29.50 \%$ & $29.66 \%$ & $29.58 \%$ & $0.11 \%$ & $0.32 \%$ & $60-20$ & $0.83 \%$ & $2.40 \%$ & Pass & 勇 \\
\hline No. 16 & 1.18 & $x$ & $10.68 \%$ & $10.66 \%$ & $10.67 \%$ & $0.02 \%$ & $0.05 \%$ & $15-10$ & $0.36 \%$ & $1.00 \%$ & Pass & 苛 \\
\hline No. 30 & $600 \mu \mathrm{m}$ & $x$ & $2.44 \%$ & $2.35 \%$ & $2.39 \%$ & $0.06 \%$ & $0.17 \%$ & $10-2$ & $0.37 \%$ & $0.40 \%$ & Pass & \\
\hline
\end{tabular}

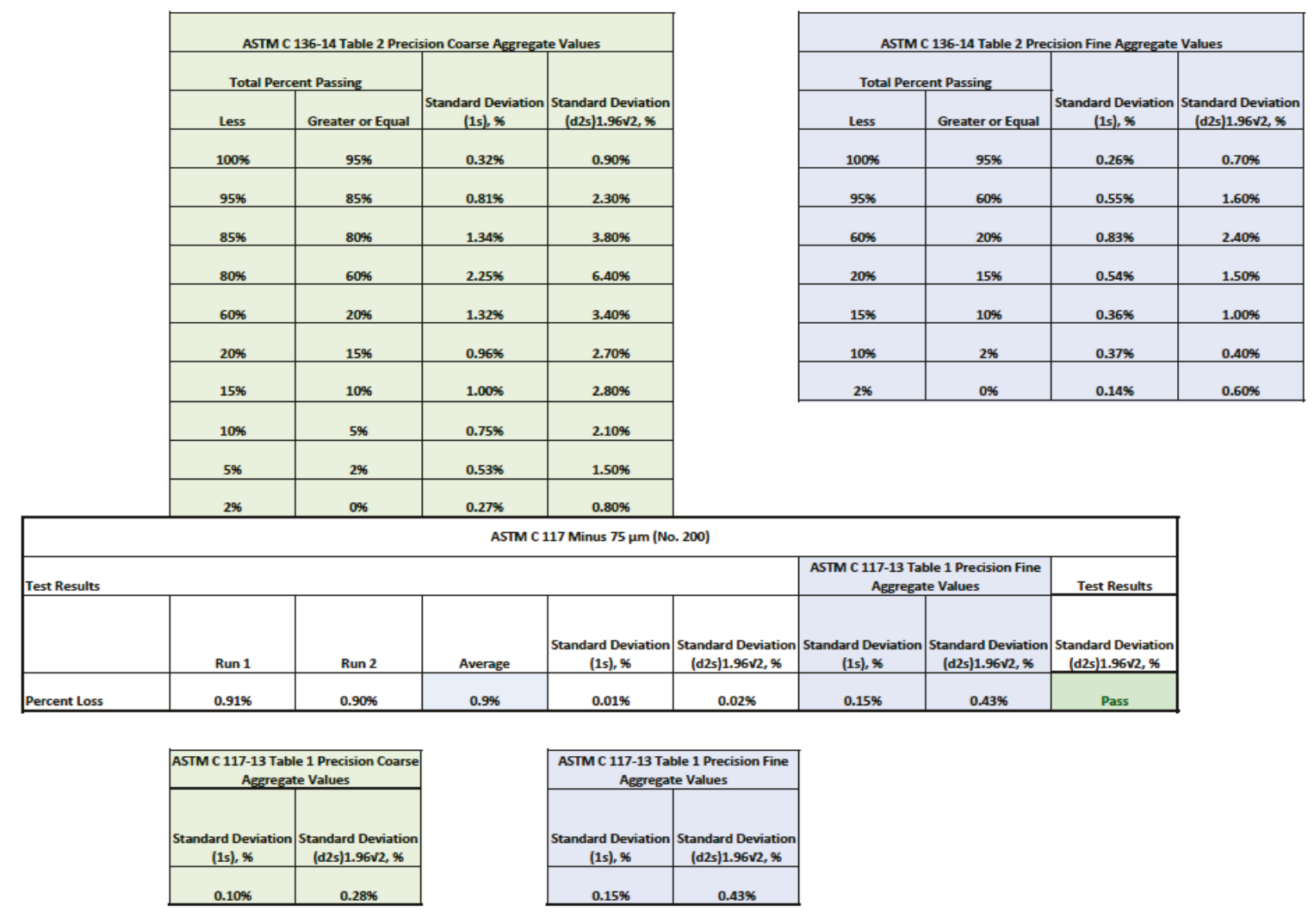


Table A11. ASTM C136, ASTM C117, and ASTM C40.

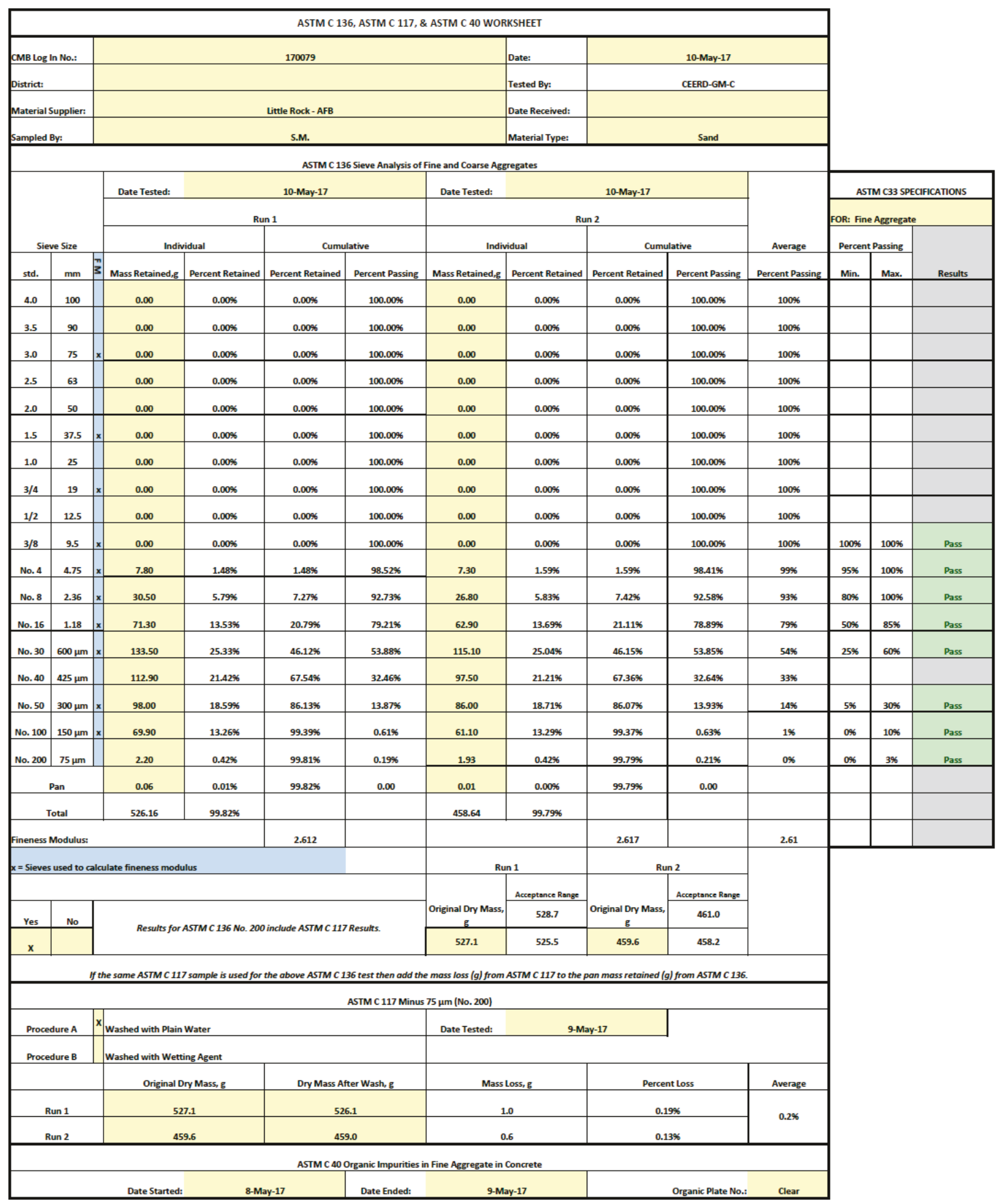


Table A12. ASTM C128.

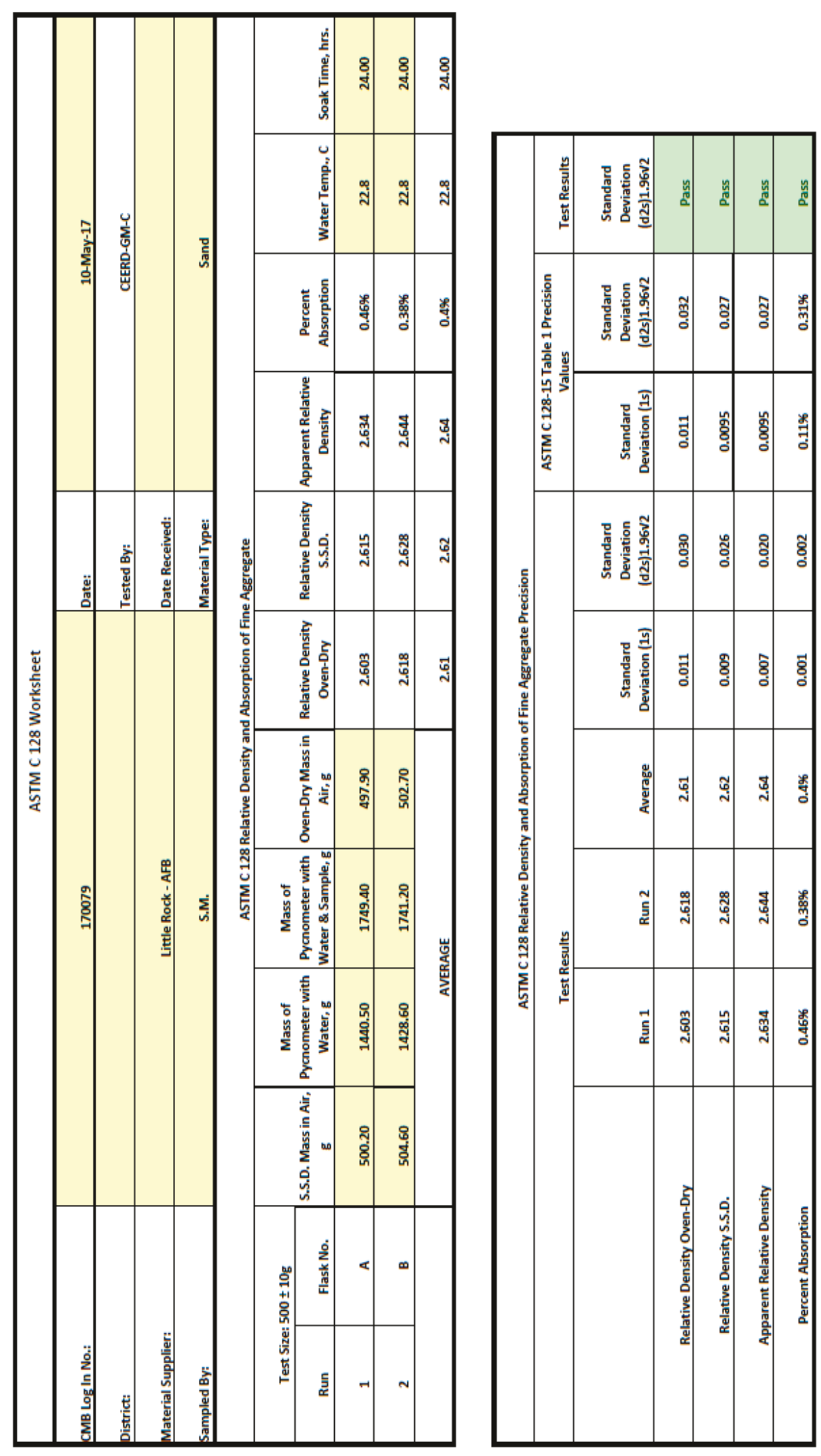


Table A13. ASTM C136 and C117 precision.

\begin{tabular}{|c|c|c|c|c|c|c|c|c|c|c|c|c|}
\hline \multicolumn{12}{|c|}{ ASTM C 136 \& C 117 PRECISION WORKSHEET } & \\
\hline \multicolumn{3}{|c|}{ CMB Log In No:: } & \multirow{2}{*}{\multicolumn{5}{|c|}{170079}} & Date: & \multicolumn{3}{|c|}{ 10-Мay-17 } & \\
\hline \multicolumn{2}{|c|}{ District: } & & & & & & & Tested By: & \multicolumn{3}{|c|}{ CEERD-GM-C } & \\
\hline Material S & upplier: & & \multicolumn{5}{|c|}{ Little Rock - AFB } & Date Received: & & & & \\
\hline \multicolumn{3}{|c|}{ Sampled By: } & \multicolumn{5}{|c|}{ S.M. } & Material Type: & \multicolumn{3}{|c|}{ Sand } & \\
\hline \multicolumn{12}{|c|}{ ASTM C 136 Sieve Analysis of Fine and Coarse Aggregates } & \\
\hline \multirow{2}{*}{\multicolumn{3}{|c|}{ Sieve Size }} & \multicolumn{5}{|c|}{ Cumulative Test Results } & \multicolumn{3}{|c|}{ ASTM C 136-14 Table 2 Precision Values } & \multirow{3}{*}{\begin{tabular}{|c} 
Test Results \\
\\
Standard Deviation \\
(d2s) 1.96V2, \%
\end{tabular}} & \\
\hline & & & \multirow{2}{*}{$\begin{array}{c}\text { Run } 1 \\
\begin{array}{c}\text { Total Percent } \\
\text { Passing }\end{array}\end{array}$} & \multirow{2}{*}{$\begin{array}{c}\text { Run 2 } \\
\text { Total Percent } \\
\text { Passing } \\
\end{array}$} & \multirow[b]{2}{*}{$\begin{array}{l}\text { Average Percent } \\
\text { Passing }\end{array}$} & \multirow[b]{2}{*}{$\begin{array}{c}\text { Standard Deviation } \\
\text { (1s), } \%\end{array}$} & \multirow[b]{2}{*}{$\begin{array}{c}\text { Standard Deviation } \\
\text { (d2s) } 1.96 \sqrt{2}, \% \\
\end{array}$} & \multirow[b]{2}{*}{$\begin{array}{l}\text { Total Percent } \\
\text { Passing }\end{array}$} & \multirow[b]{2}{*}{\begin{tabular}{|c|} 
Standard Deviation \\
(1s), $\%$
\end{tabular}} & \multirow[b]{2}{*}{$\begin{array}{c}\text { Standard Deviation } \\
\text { (d2s) } 1.96 \mathrm{~V} 2, \%\end{array}$} & & \\
\hline std. & $\mathrm{mm}$ & $\pi$ & & & & & & & & & & \\
\hline 4.0 & 100 & & $100.00 \%$ & $100.00 \%$ & $100 \%$ & $0.00 \%$ & $0.00 \%$ & & & & & \multirow{10}{*}{ 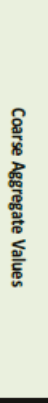 } \\
\hline 3.5 & 90 & & $100.00 \%$ & $100.00 \%$ & $100 \%$ & $0.00 \%$ & $0.00 \%$ & & & & & \\
\hline 3.0 & 75 & $x$ & $100.00 \%$ & $100.00 \%$ & $100 \%$ & $0.00 \%$ & $0.00 \%$ & & & & & \\
\hline 2.5 & 63 & & 100.009 & $100.00 \%$ & $100 \%$ & $0.00 \%$ & $0.00 \%$ & & & & & \\
\hline 2.0 & 50 & & $100.00 \%$ & $100.00 \%$ & $100 \%$ & $0.00 \%$ & $0.00 \%$ & & & & & \\
\hline 1.5 & 37.5 & $x$ & $100.00 \%$ & $100.00 \%$ & $100 \%$ & $0.00 \%$ & $0.00 \%$ & & & & & \\
\hline 1.0 & 25 & & $100.00 \%$ & $100.00 \%$ & $100 \%$ & $0.00 \%$ & $0.00 \%$ & & & & & \\
\hline $3 / 4$ & 19 & $x$ & $100.00 \%$ & $100.00 \%$ & $100 \%$ & $0.00 \%$ & $0.00 \%$ & & & & & \\
\hline $1 / 2$ & 12.5 & & $100.00 \%$ & $100.00 \%$ & $100 \%$ & $0.00 \%$ & $0.00 \%$ & & & & & \\
\hline $3 / 8$ & 9.5 & $x$ & $100.00 \%$ & 100.0096 & $100 \%$ & $0.00 \%$ & $0.00 \%$ & & & & & \\
\hline No. 4 & 4.75 & $x$ & $98.52 \%$ & $98.41 \%$ & $98 \%$ & $0.08 \%$ & $0.21 \%$ & $100-95$ & $0.26 \%$ & $0.70 \%$ & Pass & \\
\hline No. 8 & 2.36 & $x$ & $92.73 \%$ & $92.58 \%$ & 93\% & $0.11 \%$ & $0.30 \%$ & $95-60$ & $0.55 \%$ & $1.60 \%$ & Pass & \\
\hline №. 16 & 1.18 & $x$ & $79.21 \%$ & $78.89 \%$ & $79 \%$ & $0.22 \%$ & $0.61 \%$ & $95-60$ & $0.55 \%$ & $1.60 \%$ & Pass & 窟 \\
\hline No. 30 & $600 \mu \mathrm{m}$ & $x$ & $53.88 \%$ & $53.85 \%$ & $54 \%$ & $0.02 \%$ & $0.06 \%$ & $60-20$ & $0.83 \%$ & $2.40 \%$ & Pass & \\
\hline No. 40 & $425 \mu \mathrm{m}$ & & $32.46 \%$ & $32.64 \%$ & $33 \%$ & $0.12 \%$ & $0.35 \%$ & $60-20$ & 0.839 & $2.40 \%$ & Pass & $<$ \\
\hline No. 50 & $300 \mu \mathrm{m}$ & $x$ & $13.87 \%$ & $13.93 \%$ & $14 \%$ & $0.04 \%$ & $0.11 \%$ & $15-10$ & $0.36 \%$ & $1.00 \%$ & Pass & 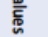 \\
\hline No. 100 & $150 \mu \mathrm{m}$ & $x$ & $0.61 \%$ & $0.63 \%$ & 19 & $0.02 \%$ & $0.05 \%$ & $2-0$ & $0.00 \%$ & $0.60 \%$ & Pass & \\
\hline No. 200 & $75 \mathrm{\mu m}$ & & $0.19 \%$ & $0.21 \%$ & 06 & $0.02 \%$ & $0.04 \%$ & $2-0$ & $0.00 \%$ & $0.60 \%$ & Pass & \\
\hline
\end{tabular}

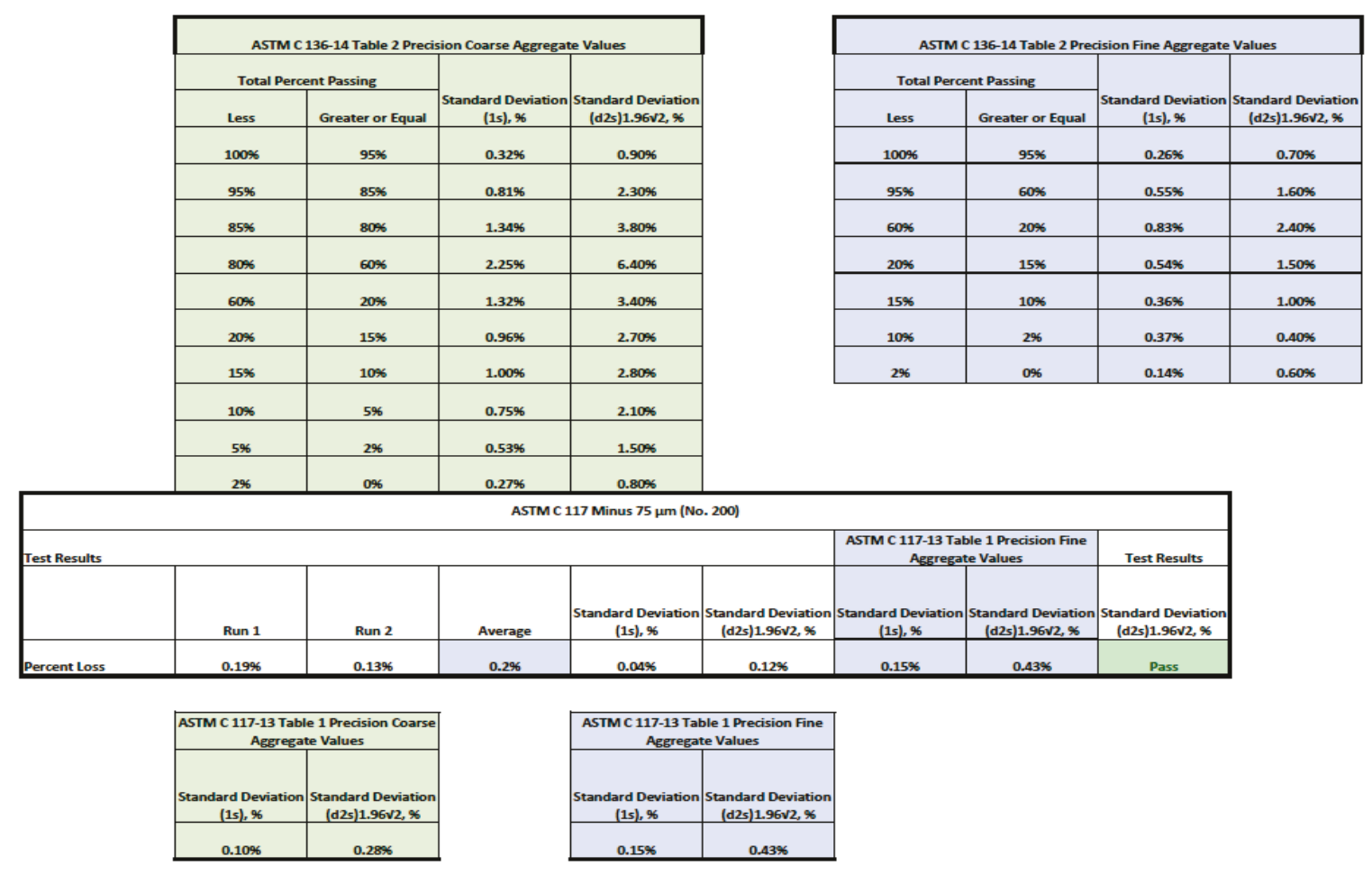




\section{Appendix B: Raw Data Sheets for Concrete Testing}


Figure B1. Three-day compressive strength $6 \times 12$ cylinder.

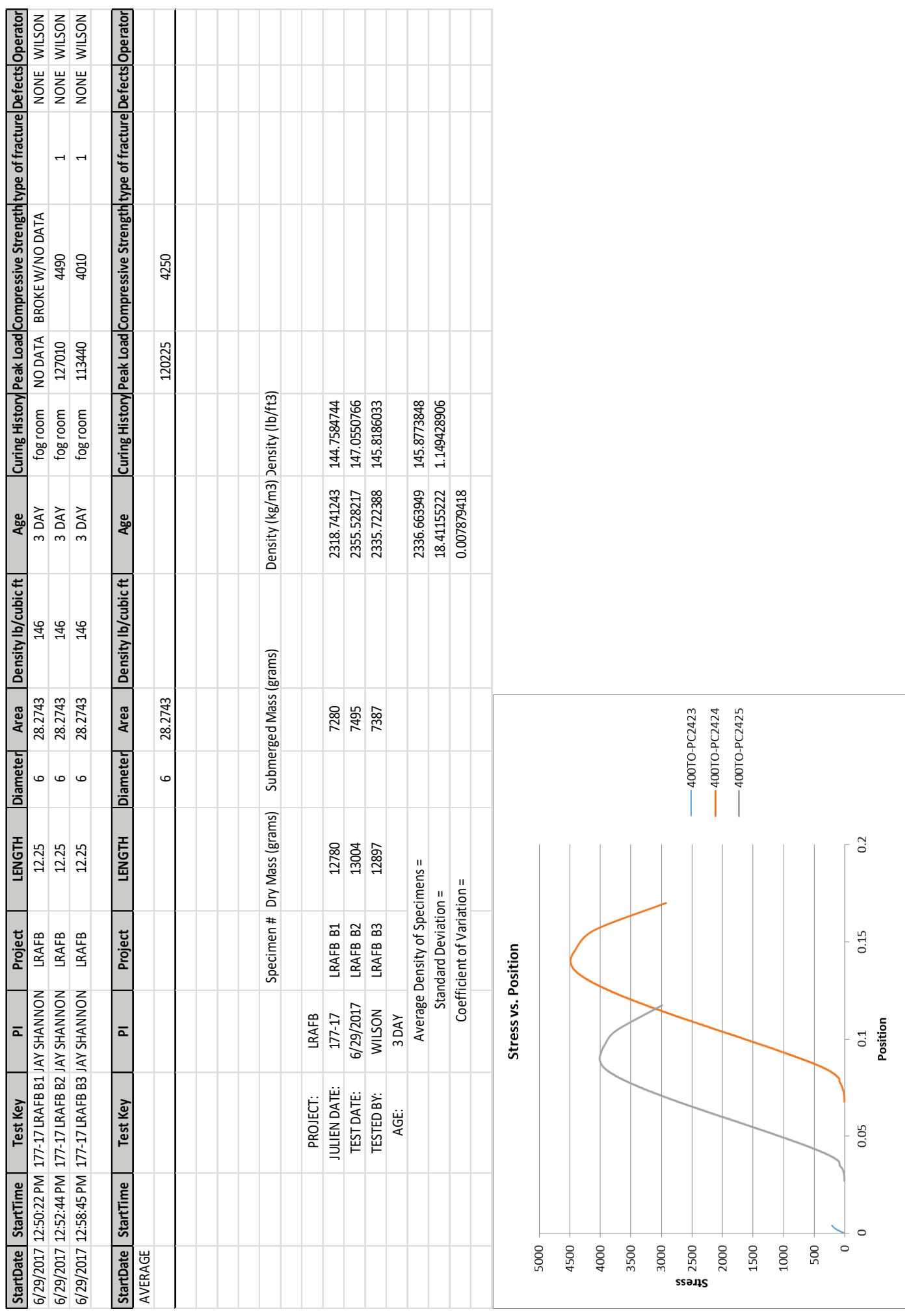


Figure B2. Seven-day compressive strength 6x12 cylinder.

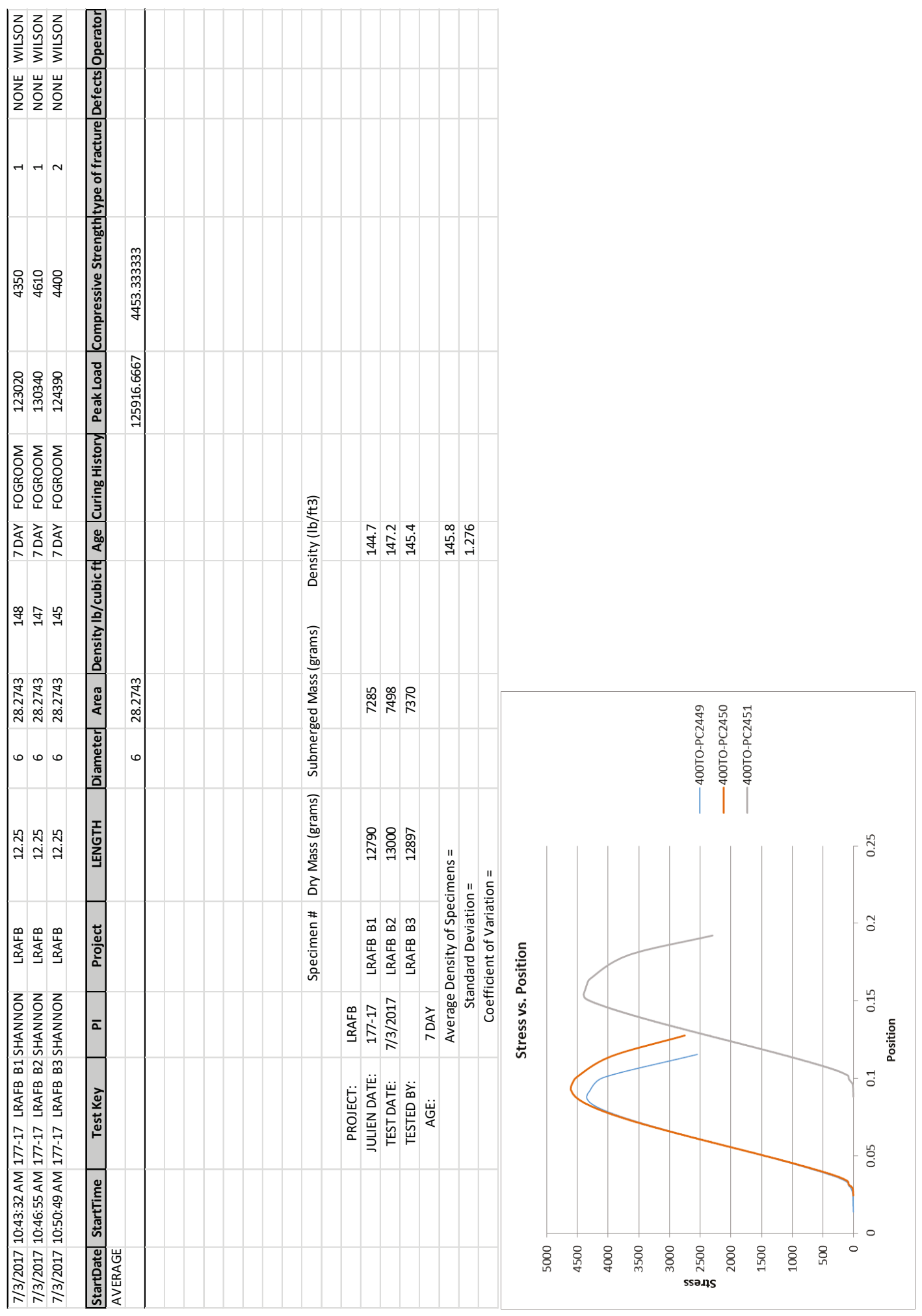


Figure B3. Fourteen-day compressive strength $6 \times 12$ cylinder.

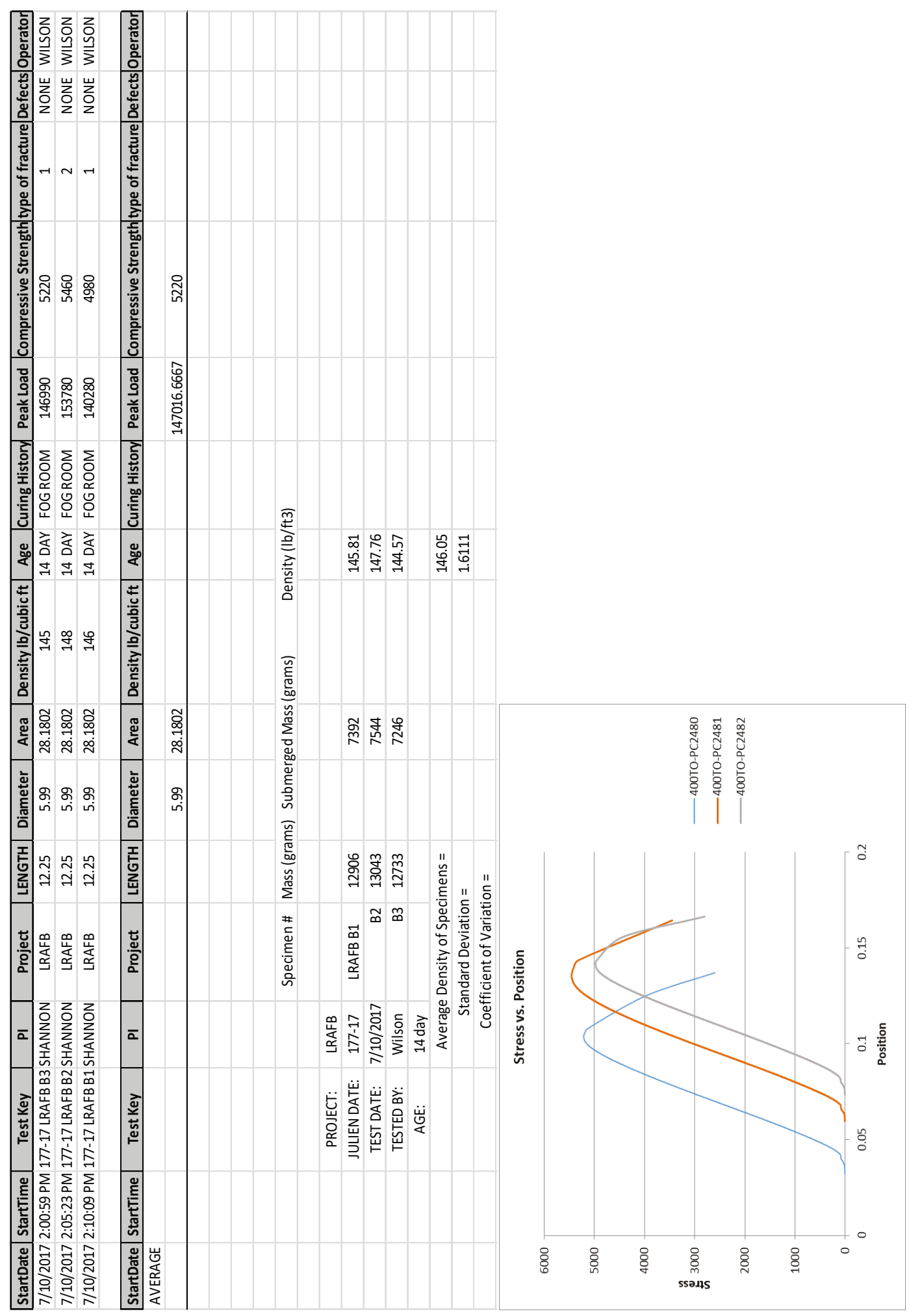


Figure B4. Twenty-eight-day compressive strength 6x12 cylinder.

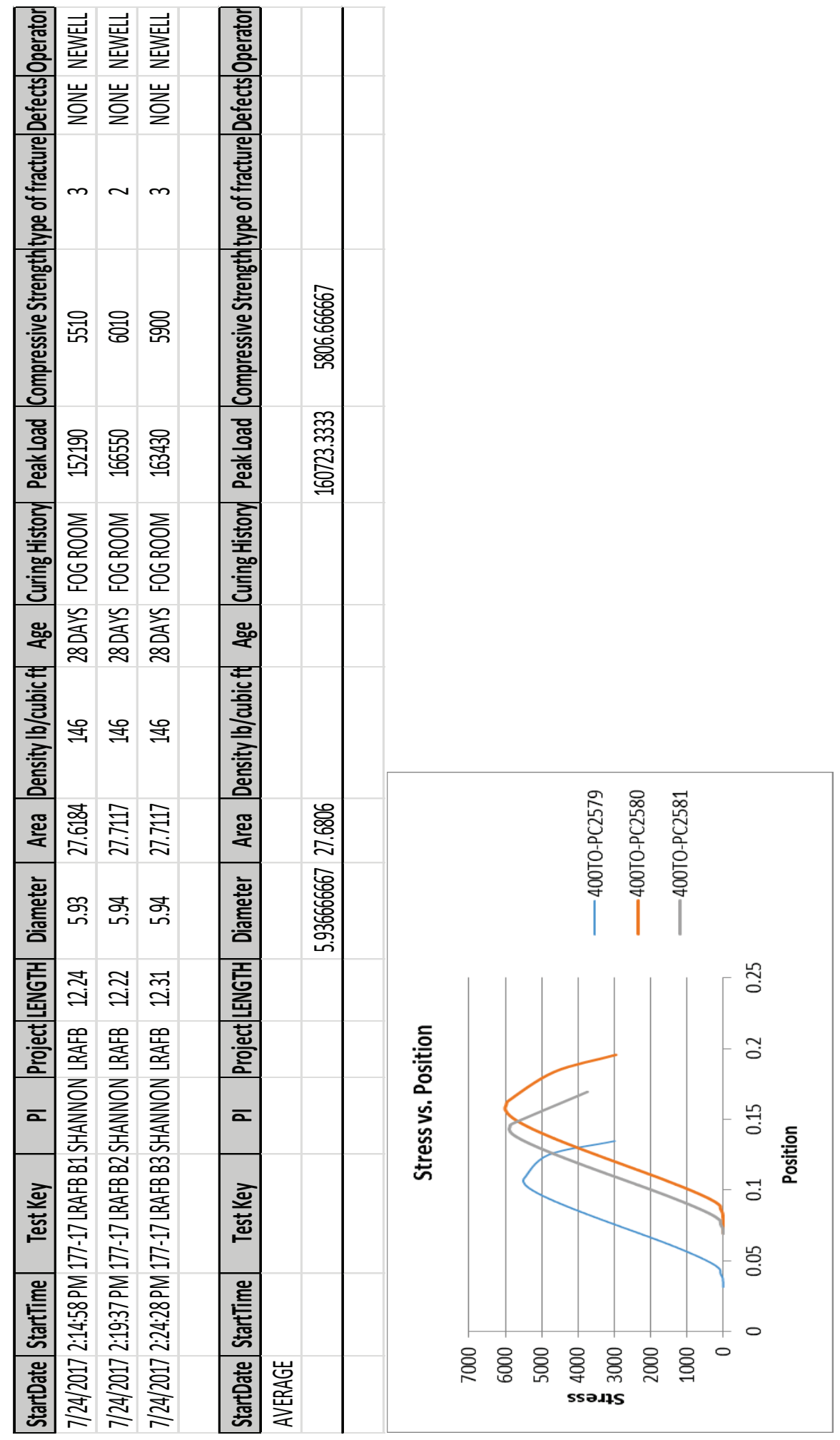


Figure B5. Three-day flexural strength $6 \times 6 \times 21$ beam.

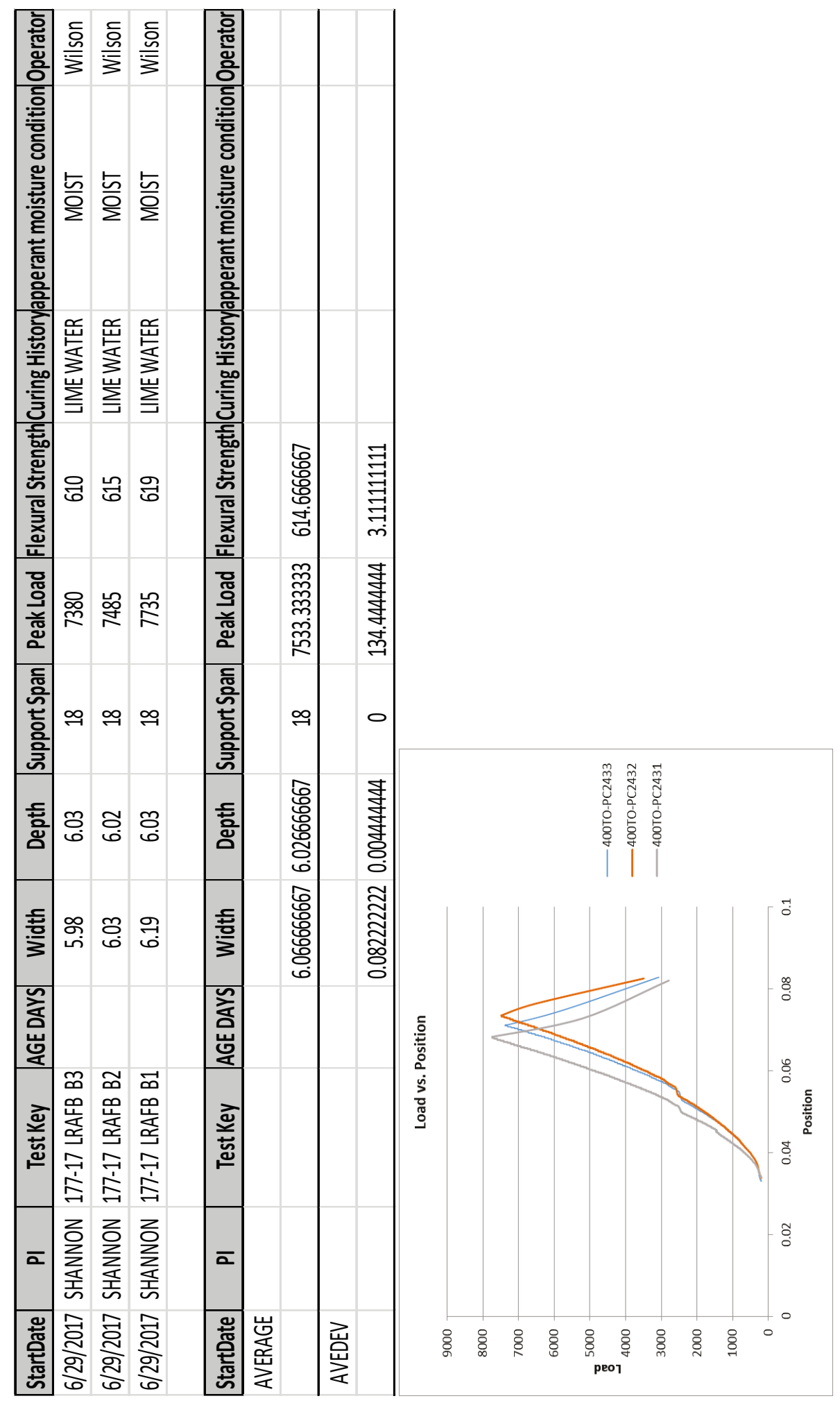


Figure B6. Seven-day flexural strength $6 \times 6 \times 21$ beam.

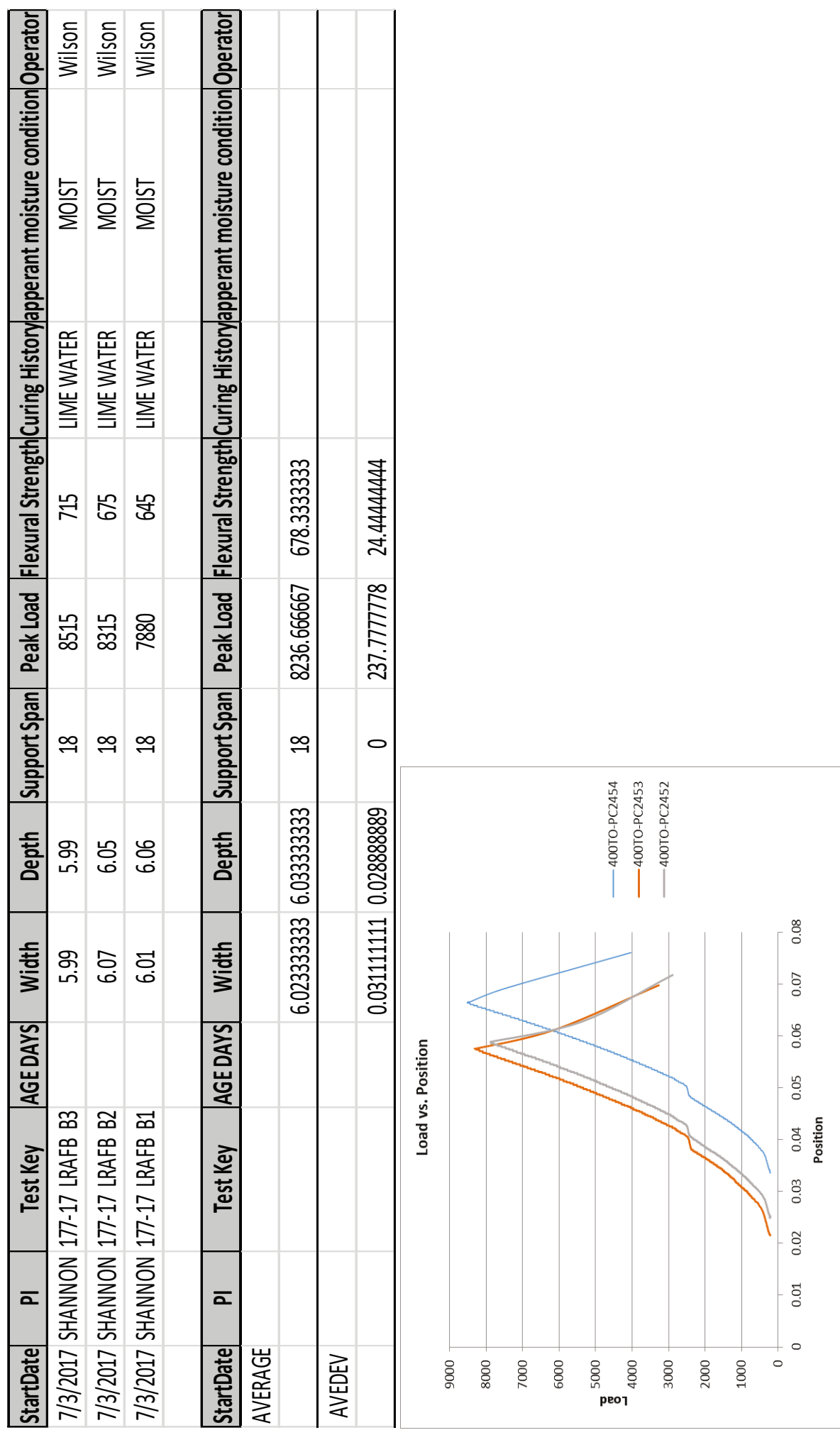


Figure B7. Fourteen-day flexural strength $6 \times 6 \times 21$ beam.

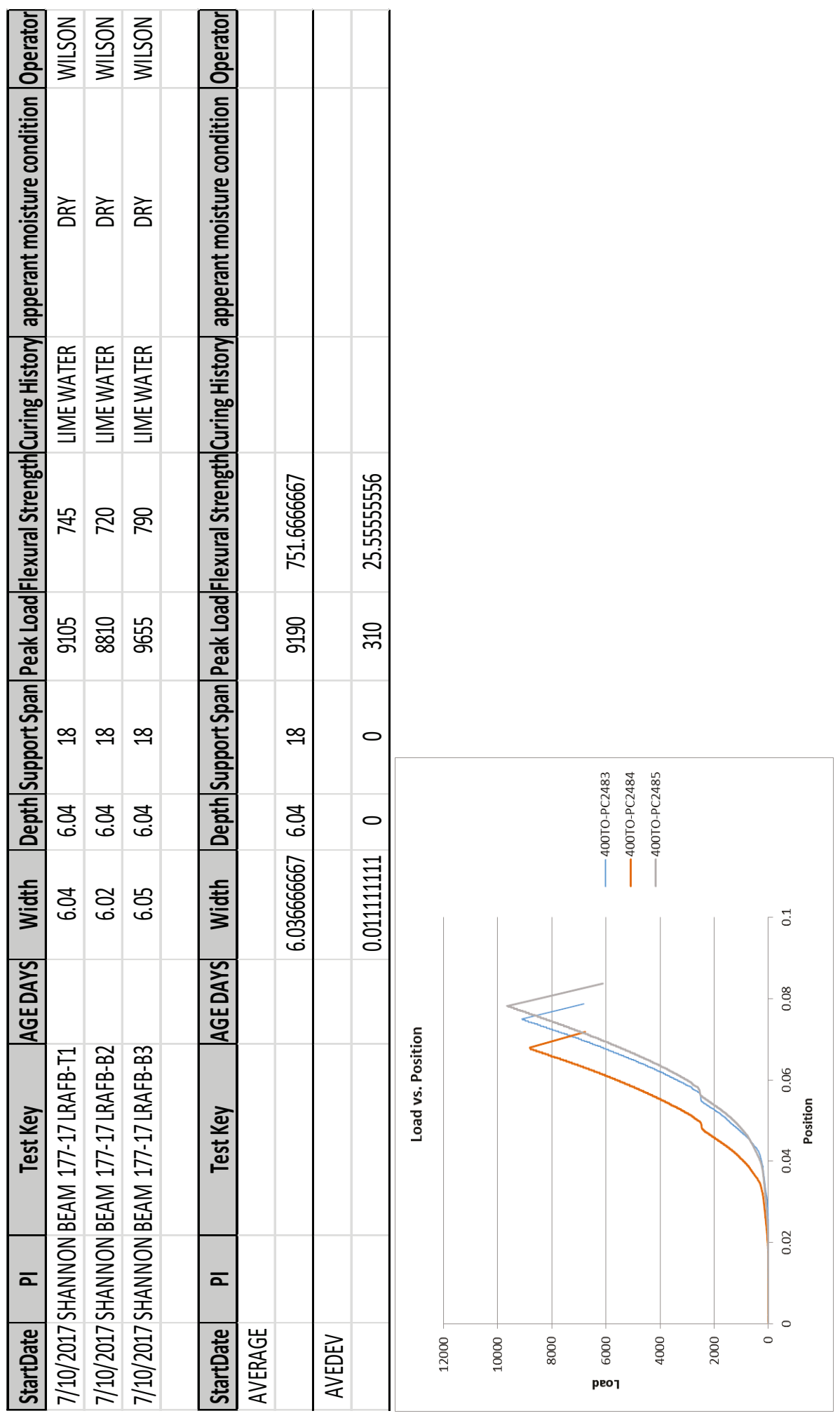


Figure B8. Twenty-eight-day flexural strength $6 \times 6 \times 21$ beam.

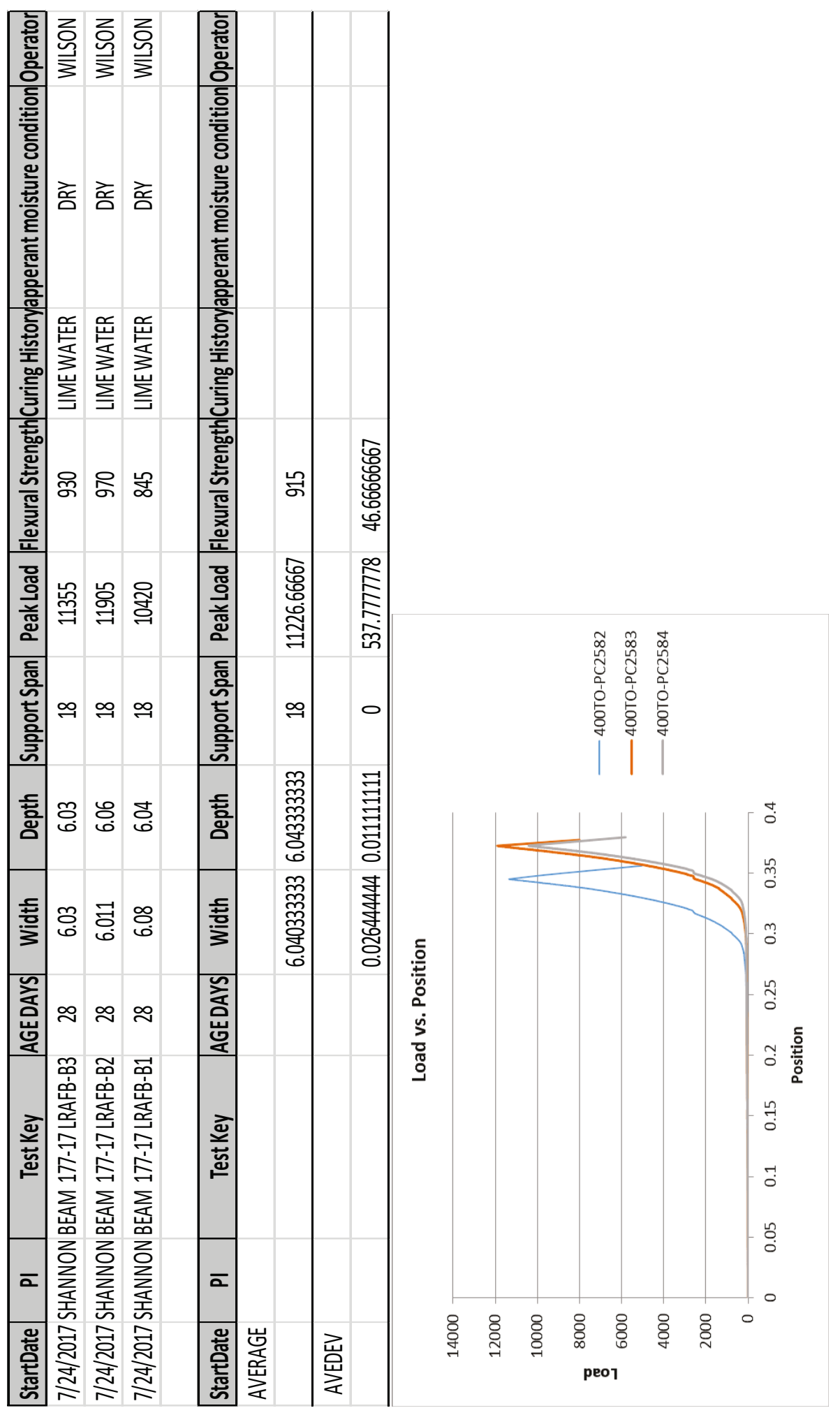




\section{REPORT DOCUMENTATION PAGE}

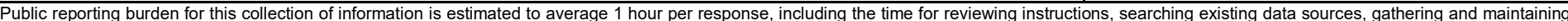

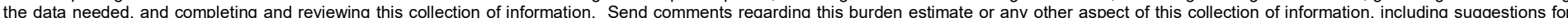

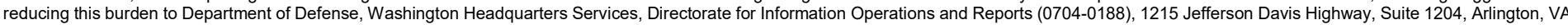

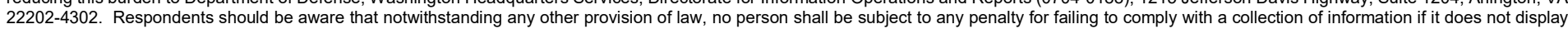
a currently valid OMB control number. PLEASE DO NOT RETURN YOUR FORM TO THE ABOVE ADDRESS.
1. REPORT DATE (DD-MM-YYYY)
November 2018

\section{TITLE AND SUBTITLE}

Little Rock Air Force Base Aggregate and Concrete Testing
3. DATES COVERED (From - To)

5a. CONTRACT NUMBER

5c. PROGRAM ELEMENT NUMBER

\section{AUTHOR(S)}

Jameson D. Shannon

5d. PROJECT NUMBER

LCC 2EF9E5

5e. TASK NUMBER

5f. WORK UNIT NUMBER

8. PERFORMING ORGANIZATION REPORT NUMBER

ERDC/GSL TR-18-32

Geotechnical and Structures Laboratory

U.S. Army Engineer Research and Development Center

3909 Halls Ferry Road

Vicksburg, MS 39180-6199

\section{SPONSORING / MONITORING AGENCY NAME(S) AND ADDRESS(ES)}

USACE Little Rock District

700 W. Capitol Ave.

Federal Building 7th Floor

Little Rock, AR 72203

\section{DISTRIBUTION / AVAILABILITY STATEMENT}

Approved for public release; distribution is unlimited.

\section{SUPPLEMENTARY NOTES}

\section{ABSTRACT}

The Little Rock Air Force Base (LRAFB) tasked the ERDC to test and evaluate a concrete mixture design and the aggregates used therein. Experimentation consisted of basic aggregate test methods such as gradation, specific gravity, absorption, and organic materials. Concrete testing consisted of manufacturing a laboratory concrete mixture design provided by LRAFB and conducting compressive and flexural strength testing of cast specimens.

In most cases the selected aggregate and concrete mixture design testing met specifications. However, there were some areas, such as aggregate gradations, in which the materials did not align with specified values or standards. Final hardened concrete properties of compressive and flexural strength met the mixture design requirements.

\begin{tabular}{|lll|}
\hline 15. SUBJECT TERMS & Workability vs Coarseness Factor & \multicolumn{2}{l}{$\begin{array}{l}\text { Runways } \\
\text { Concrete Runway } \\
\text { Power 45 Curve }\end{array}$} & Gradation & Concrete - additives \\
\hline & Little Rock Air Force Base (Ark.) & Concrete - mixing \\
\hline
\end{tabular}

\section{SECURITY CLASSIFICATION OF:}

\begin{tabular}{|l|l|}
\hline a. REPORT & b. ABSTRACT \\
Unclassified & Unclassified
\end{tabular}

17. LIMITATION OF ABSTRACT
18. NUMBER OF PAGES

\section{c. THIS PAGE \\ Unclassified}

49 19a. NAME OF RESPONSIBLE PERSON

19b. TELEPHONE NUMBER (include area code) 